\title{
How much room for a competitive electricity generation market in Portugal?
}

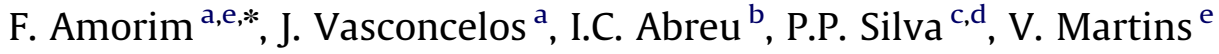 \\ a IST, Campus TagusPark, MIT Portugal - Sustainable Energy Systems, Av. Prof. Cavaco Silva, 2744-016 Porto Salvo, Portugal \\ ${ }^{\mathrm{b}}$ APREN, Associação de Energias Renováveis, Av. Sidónio Pais, 18 r/c, 1050-215 Lisboa, Portugal \\ ${ }^{\text {c }}$ Faculty of Economics, University of Coimbra, Av. Dias da Silva, 165, 3004-512 Coimbra, Portugal \\ d INESCC, Rua Antero de Quental, 199, 3000-033 Coimbra, Portugal \\ e ISEG, Technical University of Lisbon, Rua Miguel Lupi, 20, 1200-725 Lisboa, Portugal
}

\section{A R T I C L E I N F O}

\section{Article history:}

Received 1 August 2012

Received in revised form

3 October 2012

Accepted 8 October 2012

Available online 3 November 2012

\section{Keywords:}

Electricity system

Energy policy

MIBEL (Iberian Electricity Market)

\begin{abstract}
A B S T R A C T
Although the Portuguese electricity market was fully liberalized in 2006 and Iberian Electricity Market operators were set up some years ago, almost all electricity generated in Portugal benefits from a State guaranteed price, independent of market behavior. This applies not only to producers using renewable energy sources and cogeneration under feed-in tariffs, but also to all conventional power plants that undersigned a Power Purchase Agreement in the 1990s.

This paper assesses current and future amounts of electricity traded without State guaranteed price and identifies the main challenges facing the transition towards a competitive Portuguese electricity generation market in the next two decades. The electricity market of the future, freed from the present legacy generation contracts, will have to promote economic efficiency within a complex multi-variable climate/energy policy framework.
\end{abstract}

(c) 2012 Elsevier Ltd. All rights reserved.

\section{Contents}

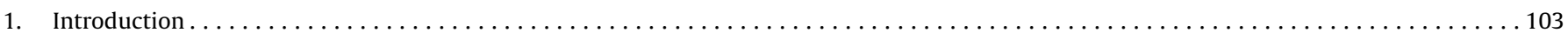

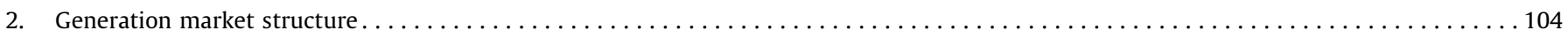

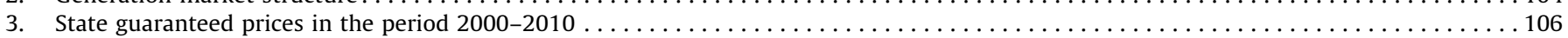

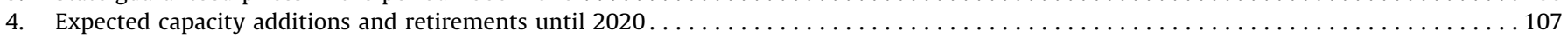

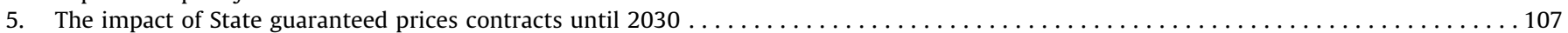

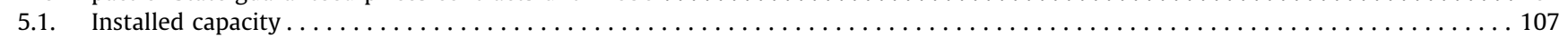

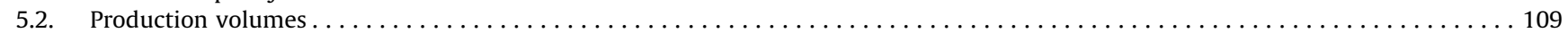

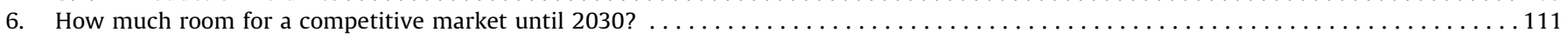

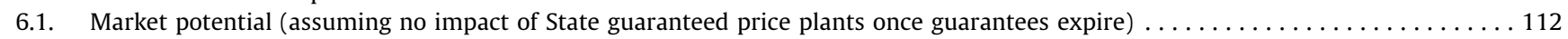

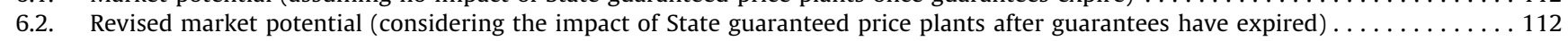

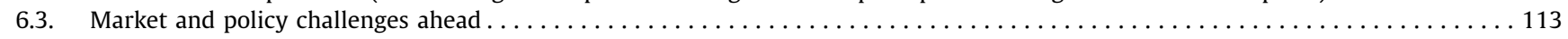

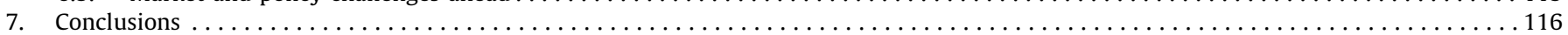

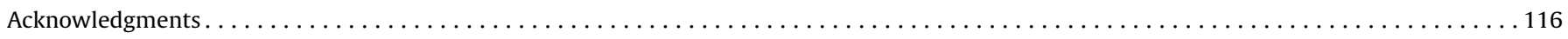

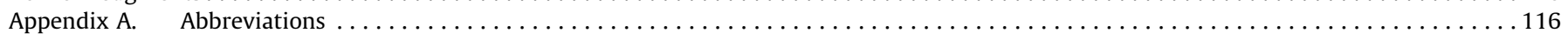

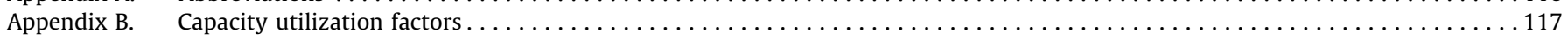

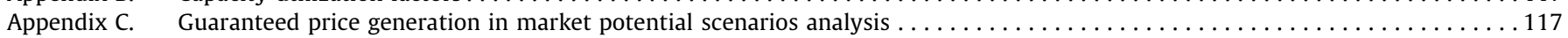

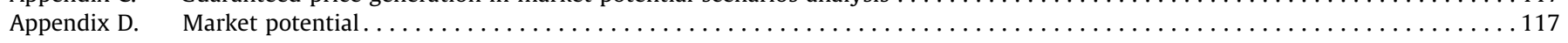

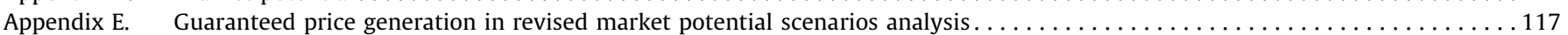

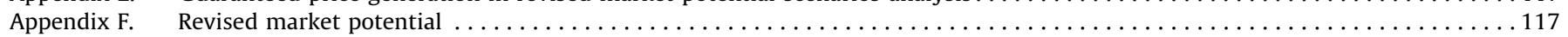

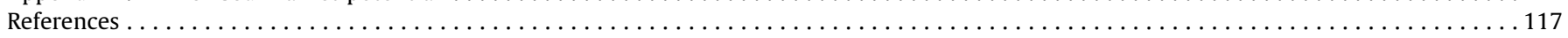

\footnotetext{
* Corresponding author at: IST, Campus TagusPark, MIT Portugal - Sustainable Energy Systems, Av. Prof. Cavaco Silva, 2744-016 Porto Salvo, Portugal. Tel.: + 351210407022 .

E-mail address: filipa.amorim@ist.utl.pt (F. Amorim).
}

\section{Introduction}

Over the last two decades the Portuguese electricity system has undergone two major legal and structural changes towards a liberalized system, in 1995 and in 2006, respectively. In 1995 the 
vertically integrated State monopoly was converted into a dual market structure, where "regulated" (Public Electricity System) and "free market" (Non-Binding Electricity System) systems operated in parallel [1-6]. The transmission and distribution systems' operators were legally unbundled, generation was liberalized in the free market system (while subject to competitive bidding and PPA in the regulated system) and retail was partially open to competition. This restructuring anticipated the 1996 IEM directive. In 2006, the dual regime was abolished in favor of the free market approach, in compliance with the 2003 IEM directive [7-9]. Moreover, distribution was legally unbundled from supply and a last-resort supplier was created. In the meantime, ownership unbundling had been applied to the transmission system operator; the retail market had been fully opened to competition and the anticipated termination of PPAs had been legally designed. In 2001, the Governments of Portugal and Spain decided to create an integrated Iberian Electricity Market (MIBEL). In July 2007, the Portuguese electricity generators operating under the so-called ordinary regime (OR) started bidding systematically into the MIBEL spot market operated by OMEL; MIBEL generators also bid regularly into the derivatives market (OMIP). Also in 2007, all PPA except two were replaced by a compensation scheme (the so-called CMEC regime) financially equivalent to the PPA [10,11]. In 2010, conventional producers who did not benefit from any of the referred guarantees became entitled to benefit from a capacity payment [12].

Since 1988, special incentives and guaranteed purchase prices have been granted to special regime (SR) generators-i.e. generators based on RES, waste and CHP. The purchase obligation from this type of generation was imposed upon the system operator first and, since 2007, upon the last-resort supplier, and hence, these generators have been left apart from the wholesale market functioning. With the regulatory framework in place in 2010, excluding capacity payments, $82 \%$ of the installed capacity in Portugal mainland (83\% of generation) enjoyed State guaranteed prices. These price guarantees are valid for several years and their costs are supported by electricity consumers. Under such circumstances, no truly competitive electricity market can fairly exist for conventional plants, for RES and CHP facilities or for ancillary services. A market where consumers do not pay the price set in the market or producers, whose decisions affect their price formation, are indifferent to its precise value is not really a market.

The difficulties in creating competitive wholesale markets have been reported in several cases either in the US $[13,14]$ or in the EU [15-20]. In Iberia, the existence of PPA associated to the high concentration of firms in the market have made a significant contribution to these difficulties as reported by $[17,18]$ in the Portuguese case or by [18-20] in the Spanish case. Nonetheless, the existence of long-term PPAs previous to the introduction of competition in markets is not an exclusive feature of the Iberian systems (e.g. also the case in Poland or Hungary), nor is the promotion of RES, CHP and waste under guaranteed prices.

The first aim of this paper is therefore to provide an up to date overview of the transition of the Portuguese electricity system into a liberalized (also decarbonized) system and highlight how the existing contracts in place, for the magnitude of the installed capacity affected relative to that of the whole system, prevent the existing wholesale market from functioning in a competitive way. The second goal is to calculate the potential for increasing the share of non-State guaranteed price electricity volumes traded in face of these contracts and of the expected evolution of the system. The last goal is to disclosure the impacts on electricity consumers. The analysis presented in this paper is based on a comprehensive set of data collected by the authors, not all publicly available, and detailed information of the regulatory developments in the Portuguese system.

Accordingly, this paper is structured as follows. The next section provides a thorough description of the transformations of the past two decades in the generation electricity system, including a perspective of the price-guaranteed production (PPA/CMEC/SR) and the electricity traded in the market without price guarantee. Section 3 analyzes the verified State guaranteed prices. Section 4 resumes the expected additions and retirements in installed capacity until 2020. Section 5 builds and analyzes scenarios considering the impact of State guaranteed prices contracts until 2030. Section 6 infers on the competitive market potential given the previous scenarios and derives some policy implications. Section 7 concludes.

\section{Generation market structure}

In 1995, the legal framework of the National Electricity System provided for the co-existence of a regulated Public Electricity System with a so-called Independent Electricity System. Generation in the Public Electricity System comprised all the power plant units owned by CPPE (former $\mathrm{EDP}^{1}$ ) as well as the two independent power producers, the $584 \mathrm{MW}$ coal-fired generation plant at Pego owned by Tejo Energia ${ }^{2}$ and the 990 MW CCGT at Tapada do Outeiro owned by Turbogás. ${ }^{3}$ All these generators sold power to the transmission company, REN, through long-term PPAs. REN bought the power at each plant according to the respective PPA and then sold it to the distributors/suppliers in charge of supplying end-users under regulated tariffs. PPAs were designed to guarantee a pre-established return on investment (8.5\% or more) during the expected economic lifetime of the plant. Each PPA was based on a formula containing a capacity charge and an energy charge. The capacity charge is a fixed value, covering investment and fixed operation and maintenance costs throughout the economic life of each plant. It depends on the actual plant capacity availability along each year and it is updated according to factors such as inflation and exchange rates. The energy charge is basically the remuneration of the power plant's variable costs. Most PPA revenues come from the capacity charge.

The Independent Electricity System comprised two separated generation components:

- Special Regime Production (SRP), which included cogeneration and most renewable production other than large hydro plants. The SRP sold power directly to REN, under special "feed-in" tariffs decided by the government under a system put in place since 1988 [21].

- Non-Binding Electricity System, which initially included a few small units and imports; this power was sold directly to

${ }^{1}$ In the 1990 s, electricity supply was the sole responsibility of EDP, a stateowned vertically and horizontally integrated company that had been formed in 1976 from the merge of several companies nationalized in 1975. Based on legislation passed between 1991 and 1994 (especially DL 7/91 and DL 131/94), the Portuguese electricity supply industry was restructured. This involved the unbundling of EDP according to business areas. The renewed company structure called "Grupo EDP", consisted then of: a holding company EDP, which coordinated the group's operation and strategy; a production company, "Companhia Portuguesa de Produção de Electricidade" (CPPE); a grid company, "Rede Eléctrica Nacional" (REN); four regional distribution companies, divided into north (EN), center (CENEL), south (SLE) and Lisbon and Tagus river valley (LTE) regions, and 10 more service companies.

2 The Pego power plant is a conventional coal-fired steam boiler. The first block came on stream in 1993, while the second block was completed in 1995. It was built by CPPE and sold to Tejo Energia, an international consortium which at the time consisted of National Power (UK, 45\%), Endesa (Spain, 35\%), EdF (France $10 \%$ ) and EDP (10\%) Today, Tejo Energia is composed of International Power (50\%), Endesa Generación (38.9\%) and EDP (11.1\%).

3 The Tapada do Outeiro CCGT came progressively on stream in 1998 and 1999. The plant is situated near Porto and it is owned by Turbogás. At the time, a consortium of PowerGen (50\%), RWE Energie (25\%), Siemens Project Ventures (10\%), EDP (10\%) and Koch Transporttechnik (5\%). Since June 2008, Tapada do Outeiro is $100 \%$ owned by International Power Portugal (IPP). In February 2011 International Power and GDF SUEZ Energy International combined. GDF SUEZ became majority shareholder of International Power with approx. 70\%. 
eligible consumers, i.e. those having the right to choose their power supplier. In the period 2003-2005 3CCGT units of 392 MW each, owned by EDP, went into operation.

In 2004, new legislation was approved that gave all electricity consumers the right to choose supplier. Also in 2004, a separate decree-law, previously submitted to and approved by the European Commission (DGC), defined the compensation scheme (CMEC regime) for generators willing to exit PPAs that provides the same financial return and risk profile as the PPAs for generators willing to exit PPAs [10]. The final CMEC compensation results from the difference between the net present value of the PPA, calculated at the date of the early termination, and the actual revenue obtained in the free market, including system services. A base fixed CMEC fee is received by the producer through tariffs over the 20.5 years lifetime of the CMEC's system corresponding to capacity payments. The CMEC variable payment is provisionally estimated considering the expected revenues in the free market, which are obtained by multiplying the estimated production of each plant by a reference annual average market price of $50 € / \mathrm{MWh}$ [22]. The deviations resulting from the difference between CMECs estimation main assumptions (such as output levels, market prices or fuel costs) and actual market data are finally adjusted and included in electricity tariffs 2 years after market occurrence $(9 / 12$, on a provisional basis, after one year and permanently set after 2 years): if CMEC producers' revenues from the market exceeded the net present value of the respective PPA, CMEC producers have to return the difference to all consumers (thus lowering future regulated tariffs); on the contrary, if revenues were below the PPA net present value, CMEC producers are paid the remaining by all consumers (through regulated tariffs). Presently, two PPAs are still in place while the others were replaced in June 2007 by the CMEC scheme to accomplish the increase in liquidity of the Iberian electricity wholesale market [11]. Fig. 1 shows the total amount of PPA contracted capacity at the end of 2004 and the aggregated duration of these contracts [23].

A new comprehensive electricity framework, replacing the old 1995 one, was established in 2006 [7-9]. According to the 2006 legislation, generation of electricity is now divided into two regimes:

- Ordinary regime (OR) - generation of electricity through conventional non-renewable thermal sources and large hydroelectric plants.

- Special regime (SR) - generation from endogenous and RES (except large hydro) and CHP.

The OR is composed by the following players:

- previous incumbent EDP, which remains the country's largest electricity generator, with the power plants under CMEC

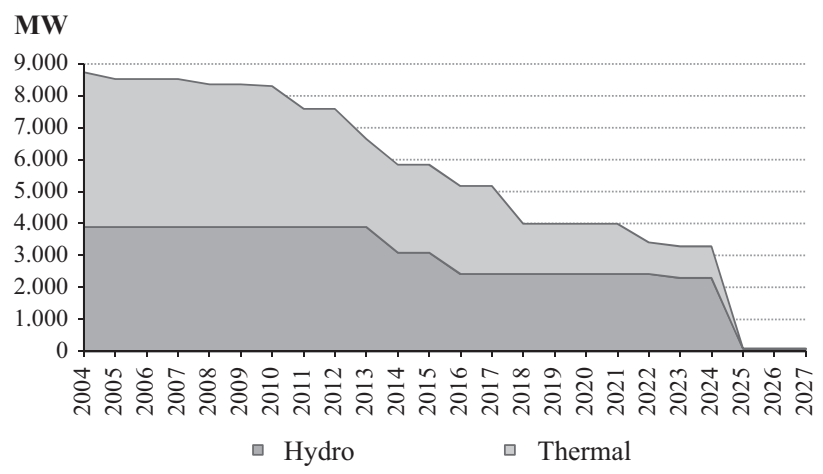

Fig. 1. Total PPA contracted capacity. Status: 2004.

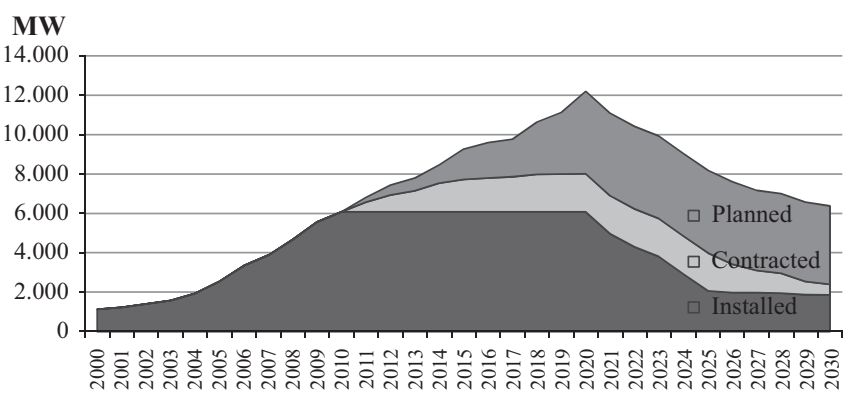

Fig. 2. Total special regime (SR) capacity. Status: 2010

regime and some additional thermal and hydro units without such guarantees, operating on a free market basis ${ }^{4}$;

- two thermal independent power producers, Tejo Energia (Pego) and Turbogás (Tapada do Outeiro), who still keep their PPAs. ${ }^{5}$

The SR is composed by a myriad of players using different technologies and belonging to several promoters with different market shares. Special regime generators sell their output at a guaranteed price (usually called "feed-in tariff") for a certain period of time (varying according to technology and to the applicable feed-in tariff regime). Fig. 2 shows the total amount of SR capacity at the end of 2010 and the combined duration of these contracts. SR capacity was considered according to its situation at the end of 2010, namely: plants connected to the grid and operating at the end of 2010 (installed); plants with licenses assigned through tenders (wind, biomass, and solar) but not yet built or functioning (contracted); the capacity foreseen in the NREAP_National Renewable Energy Action Plan 2020 (planned). A few adjustments have been made on the scheduled years of entering into operation of some plants, in the case of contracted and planned capacities, in order to take into account already identified delays. As it can be seen in Fig. 2, in any of the SR scenarios, price guarantees are valid for several year after an installation enters into functioning. By 2020 the planned capacity expansion is expected to double the installed capacity in the end of 2010. Also it will be only by 2020 that price guarantees will begin to come to an end.

Table 5 (Section 4) and Table 1 show total installed capacity and production by technology at the end of 2010, respectively [24-31]. Out of a total of $17.908 \mathrm{MW}$ installed capacity at the end of 2010, 14.593 MW (82\%) have a guaranteed price independent from market conditions: $5.923 \mathrm{MW}$ (33\%) corresponds to feed-in tariff guarantees; $1.574 \mathrm{MW}(9 \%)$ corresponds to the two remaining PPAs and 7.096 MW (40\%) corresponds to CMEC. Similarly, out of 52.2 TWh of electricity available for consumption in 2010, $43 \mathrm{TWh}$ (83\%) have a guaranteed price independent from market conditions: $17.9 \mathrm{TWh}$ (34\%) from feed-in tariff guarantees; 6.7 TWh (13\%) from the two remaining PPAs, and 18.9 TWh (38\%) from the CMEC. The wholesale electricity market potential can be seen as the amount of electricity produced without price guarantees. In the period 2000-2010, this corresponds to thermal other than PPA/CMECs, hydro other than PPA/ CMECs and imports balance net of hydro pumping.

Table 1 also describes the evolution of electricity production and consumption between 2000 and 2010, identifying the different

\footnotetext{
${ }^{4}$ Capacity payments introduced by [12] are not taken into account. These are the cases of the Ribatejo CCGT power plant, located $30 \mathrm{~km}$ north of Lisbon, which came on stream in 2004/05; nine large hydro plants (Alqueva, Belver, Desterro, Lindoso, Ponte de Jugais, Sabugueiro I, Santa Luzia, Varosa e Vila Cova) which started operation before 2004; the Lares CCGT power plant, which came on stream in 2009.

${ }^{5}$ The Pego II CCGT power plant, which started operation in 2011, operates in the free market, without PPA.
} 
Table 1

Electricity consumption in Portugal mainland with and without state guaranteed price in 2000-2010.

\begin{tabular}{|c|c|c|c|c|c|c|c|c|c|c|c|}
\hline TWh & 2000 & 2001 & 2002 & 2003 & 2004 & 2005 & 2006 & 2007 & 2008 & 2009 & 2010 \\
\hline Hydro CMEC & 10.2 & 12.6 & 6.8 & 14.0 & 8.7 & 4.3 & 9.6 & 8.6 & 5.6 & 6.9 & 13.5 \\
\hline Hydro free & 0.6 & 0.8 & 0.5 & 0.7 & 0.5 & 0.2 & 0.6 & 0.9 & 0.9 & 1.0 & 1.3 \\
\hline Thermal PPA/CMEC & 24.3 & 24.3 & 29.4 & 22.2 & 22.3 & 25.5 & 19.8 & 17.4 & 16.3 & 17.0 & 11.6 \\
\hline Thermal free & 0.0 & 0.0 & 0.0 & 0.2 & 3.4 & 5.1 & 5.7 & 6.0 & 7.5 & 6.7 & 5.7 \\
\hline Special regime & 2.5 & 2.6 & 2.8 & 3.7 & 4.4 & 6.5 & 8.7 & 10.1 & 11.5 & 14.4 & 17.9 \\
\hline Other CHP & 1.2 & 1.1 & 1.2 & 1.5 & 2.0 & 2.5 & 2.8 & 3.3 & 3.0 & 3.6 & 4.4 \\
\hline RES CHP & 0.1 & 0.1 & 0.1 & 0.1 & 0.4 & 1.3 & 1.5 & 1.5 & 1.5 & 1.5 & 1.7 \\
\hline Biomass & 0.0 & 0.0 & 0.0 & 0.0 & 0.1 & 0.1 & 0.1 & 0.1 & 0.1 & 0.3 & 0.6 \\
\hline Biogas & 0.0 & 0.0 & 0.0 & 0.0 & 0.0 & 0.0 & 0.0 & 0.0 & 0.1 & 0.1 & 0.1 \\
\hline MSW\&IR & 0.4 & 0.4 & 0.4 & 0.5 & 0.4 & 0.5 & 0.5 & 0.4 & 0.4 & 0.5 & 0.5 \\
\hline Small hydro & 0.6 & 0.7 & 0.7 & 1.0 & 0.7 & 0.4 & 1.0 & 0.7 & 0.7 & 0.8 & 1.4 \\
\hline Wind & 0.2 & 0.2 & 0.3 & 0.5 & 0.8 & 1.7 & 2.9 & 4.0 & 5.7 & 7.5 & 9.0 \\
\hline Solar & 0.0 & 0.0 & 0.0 & 0.0 & 0.0 & 0.0 & 0.0 & 0.0 & 0.0 & 0.1 & 0.2 \\
\hline Import balance & 0.9 & 0.2 & 1.9 & 2.8 & 6.5 & 6.8 & 5.4 & 7.5 & 9.4 & 4.8 & 2.6 \\
\hline Hydro pumping & 0.6 & 0.5 & 0.7 & 0.5 & 0.4 & 0.6 & 0.7 & 0.5 & 0.6 & 0.9 & 0.5 \\
\hline Total demand & 37.9 & 40.0 & 40.7 & 43.1 & 45.5 & 47.9 & 49.2 & 50.1 & 50.6 & 49.9 & 52.2 \\
\hline PHI & 1.08 & 1.19 & 0.75 & 1.33 & 0.83 & 0.41 & 0.98 & 0.77 & 0.56 & 0.77 & 1.30 \\
\hline PWI & & 1.05 & 1.05 & 1.00 & 0.91 & 0.97 & 0.94 & 0.93 & 1.01 & 1.03 & 1.08 \\
\hline No price guarantee (\%) & 3 & 1 & 4 & 8 & 22 & 24 & 23 & 28 & 34 & 23 & 17 \\
\hline
\end{tabular}

sources with and without guaranteed prices in addition to the Productibility Hydroelectric Index (PHI) and the Productibility Wind Index (PWI) in each year [24,26-31]. The electricity volumes available in the "free market" from each source vary according to several factors such as available technology mix in the system, availability of natural resources, in particular rain (which translates into the Productibility Hydroelectric Index, PHI) and wind (which translates into the Productibility Wind Index, PWI), oil prices, $\mathrm{CO}_{2}$ prices (since 2007) and, in the case of imports, the relative electricity prices between Portugal and Spain.

Finally, in Table 1, the relative importance of electricity freely traded in the market are expressed, i.e. without price guarantees, relative to total consumption (final consumption plus network losses). The years 2004-2009 were extremely dry (with the exception of 2006); moreover, in this period, wholesale electricity prices were about 10\% higher in Portugal than in Spain, thus leading to substantial imports on economic grounds (imports were not higher because, until 2009, congestion at the interconnections happened more than $50 \%$ of the time).

\section{State guaranteed prices in the period 2000-2010}

Fig. 3 shows the guaranteed average prices per generator type in Portugal mainland [27-31,34-37]. These prices are the prices really received by producers ${ }^{6}$-i.e. after taking into account all differences between forecasts included ex ante in the regulated tariffs for year $t$ and ex post adjustments made in years $t+1$ and $t+2$, based on actual data, and excluding hydrological corrections. The hydrologic correction fund exists to address the financial risks associated with the variability of costs with the purchase of electricity resulting from the variability of hydro power generation, caused by irregular interannual hydrologic inflows. When a year is dry ( $\mathrm{PHI}<1$ ), less hydro generation (more thermal generation) means a relatively higher electricity price: for producers this represents relatively higher revenues; while for consumers the resulting deficit is paid by the fund. When a year is wet $(\mathrm{PHI}>1)$, less thermal generation

${ }^{6}$ All prices are final except those referring to PPA/CMEC producers in 2010 (provisional).

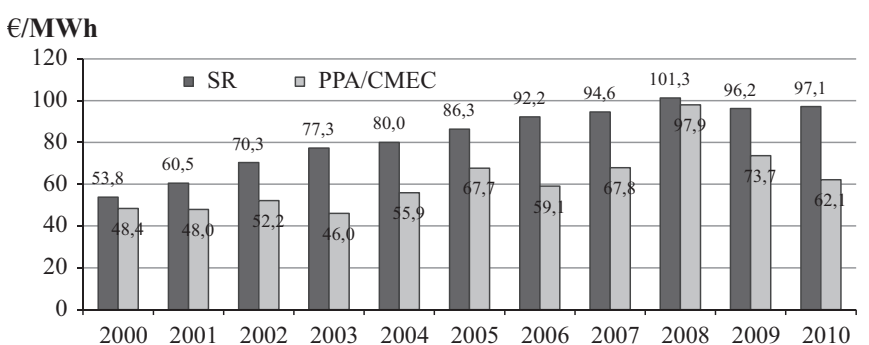

Fig. 3. Comparison of average current prices per generator type.

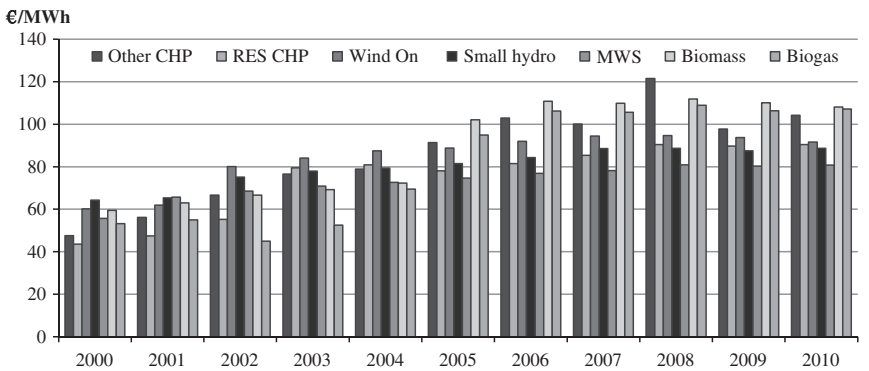

Fig. 4. SR average current prices per technology, except for PV.

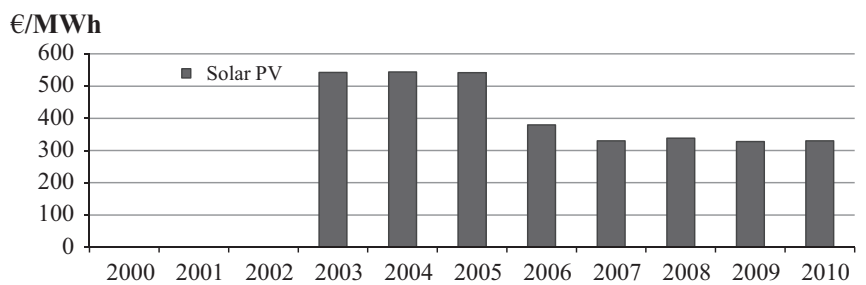

Fig. 5. PV average current prices.

(more hydro generation) means a relatively lower electricity price: for producers this represents relatively lower revenues; while for consumers the resulting surplus adds to the fund. 
Table 2

Total PPA/CMEC and SR production costs in relation to final consumption expenditure in current prices in Portugal.

\begin{tabular}{|c|c|c|c|c|c|c|c|c|c|c|c|}
\hline Year & 2000 & 2001 & 2002 & 2003 & 2004 & 2005 & 2006 & 2007 & 2008 & 2009 & 2010 \\
\hline \multicolumn{12}{|c|}{ PPA/CMEC } \\
\hline TWh & 34 & 37 & 36 & 36 & 31 & 30 & 29 & 26 & 22 & 24 & 25 \\
\hline Meuro & 1.671 & 1.771 & 1.885 & 1.662 & 1.734 & 2.019 & 1.734 & 1.766 & 2.178 & 1.769 & 1.563 \\
\hline$\%$ FCE & 1.6 & 1.6 & 1.6 & 1.4 & 1.4 & 1.5 & 1.3 & 1.2 & 1.5 & 1.2 & 1.0 \\
\hline \multicolumn{12}{|c|}{ SR-RES } \\
\hline TWh & 1 & 1 & 2 & 2 & 2 & 4 & 6 & 7 & 9 & 11 & 13 \\
\hline Meuro & 78 & 93 & 119 & 166 & 196 & 333 & 519 & 636 & 805 & 1.034 & 1.275 \\
\hline$\% \mathrm{FCE}$ & 0.1 & 0.1 & 0.1 & 0.1 & 0.2 & 0.3 & 0.4 & 0.4 & 0.5 & 0.7 & 0.8 \\
\hline \multicolumn{12}{|c|}{ SR-NRES } \\
\hline TWh & 1 & 1 & 1 & 2 & 2 & 3 & 3 & 3 & 3 & 4 & 4 \\
\hline Meuro & 55 & 61 & 79 & 119 & 162 & 232 & 289 & 326 & 366 & 351 & 467 \\
\hline \%FCE & 0.1 & 0.1 & 0.1 & 0.1 & 0.1 & 0.2 & 0.2 & 0.2 & 0.2 & 0.2 & 0.3 \\
\hline
\end{tabular}

Figs. 4 and 5 show the SR guaranteed average prices, also presented in Fig. 3, but with more detail: Fig. 4 shows current average prices per SR technology, except for PV, whose average current prices for scale reasons are shown in Fig. 5. In Fig. 4 one can observe that for "Other CHP" the increasing price trend was kept until 2006, then was broken in 2007 to achieve a peak in 2008 and then break again to approx. previous levels; for "RES CHP" somewhat abrupt increase occurred in 2003, while for the rest of the period prices kept a moderate increasing trend; for "Wind" and "Small hydro" the increasing prices trend has tended to stability in more recent years; for "MWS" tenuous increases can be observed along the whole period; and, for "Biomass" and "Biogas", in 2005 a fairly abrupt increase in average prices can be detected. Fig. 5 shows a downward trend during the first years of PV large scale commercial application, which since 2007, has remained at quite constant levels.

Table 2 shows the total costs these prices represent for electricity consumers, per producer type, also in proportion of the Final Consumption Expenditure (FCE), at current prices. This table shows that in 2010 total guaranteed price payments to electricity producers represented $2.1 \%$ of Final Consumption Expenditure [25,27-31,34-38].

\section{Expected capacity additions and retirements until 2020}

Spanish generators Endesa and Iberdrola, as well as EDP, Elecgás and Galp Energia all have already received licenses to build new CCGT and/or hydro power plants. ${ }^{7}$ From 2011 to 2020, significant changes are expected in the ordinary generation structure, shown in Table 3 [40-44]: an expected net decrease of $925 \mathrm{MW}$ thermal capacity and a net increase of $4.992 \mathrm{MW}$ hydro new capacities, 3.936 MW of which are reversible hydro plants. 2.077 MW CCGT new capacity is expected to start operation until 2017. These new thermal plants will replace $3.000 \mathrm{MW}$ older thermal capacities to be decommissioned until then: Carregado $(710 \mathrm{MW})$ and the remaining units at Tunes (165 MW) by 2011; the oil-fired plant at Setúbal (948 MW) by 2012; and, the coal-fired plant at Sines (1.180 MW) by 2017 . Ten new hydro-generation units will start operation by the end of 2020, adding 3.036 MW of new installed capacity. Moreover, six hydro repowering projects are also planned, including Picote II (246 MW), Bemposta II (191 MW), Alqueva II (256 MW), Venda Nova III (736 MW), Salamonde II (207 MW) and Paradela II (320 MW), adding further 1.956 MW.

In the SR, ambitious targets are set to be accomplished by 2020 , according to policy goals first established in 2001 and since then

\footnotetext{
${ }^{7}$ For competition purposes, licensing limits are in place, capping any market participant's capacity at $40 \%$ of Portuguese MIBEL capacity or $50 \%$ maximum in portfolio for each primary source [39].
}

successively amplified. Table 4 presents these capacity targets to be put in place in order to allow the electricity sector to achieve $60 \%$ renewable electricity production by $2020[25,42,44]$.

According to planned capacity additions and retirements foreseen in Tables 3 and 4, the situation in 2020 is expected to be seen in Table 5 [25,42-44]. Table 5 shows that large hydro (OR) is the technology that will represent the highest share of total installed capacity in 2020 (34\%). Wind is expected to represent the second highest share (25\%), including wind offshore. Thermal installed capacity in 2020 is expected to be halfed from $41 \%$ to $22 \%$ of total installed capacity and achieve the third highest share. Most of thermal capacity will be based on natural gas, both in OR and in SR (the case of CHP). The technology with the highest increment of installed capacity until 2020 is expected to be solar, including PV and concentrated solar thermal, from $1 \%$ to $6 \%$ share of installed capacity.

Finally, interconnection with Spain is expected to increase by $1.200 \mathrm{MW}$ in $2014 / 2015$, to $3.000 \mathrm{MW}$ of commercially available capacity [44]. This will represent about $25 \%$ of Portuguese peak demand, which is more than the minimum amount agreed at the European Council of March $2002 .^{8}$

\section{The impact of State guaranteed prices contracts until 2030}

\subsection{Installed capacity}

Most of the existing installed capacity and a large share of the capacity to be added until 2020 will benefit from guaranteed prices for a long period of time, thus leaving little room for a free electricity generation market. Figs. 6 and 7 show the duration of State guaranteed price contracts for thermal and large hydro power capacity, respectively. Fig. 8 shows the duration of SR price guarantees, including those foreseen until 2020 in the NREAP. For each SR unit installed at the end of 2010 the duration of the guaranteed feed-in tariff foreseen in the applicable legislation was considered. Feed-in tariffs durations are summarized in Table 6, for RES and waste plants, and in Table 7, for CHP plants. From 2011 on, the published results of capacity tenders (wind, biomass and solar) along with the National Technology Road Map 2020 targets (Table 5) were considered.

As can be seen in Fig. 6, the contracted PPA/CMEC thermal capacity has remained quite constant until 2010, when it achieved approx. $4.410 \mathrm{MW}$ ( $25 \%$ of total installed capacity). These longterm contracts for conventional thermal power plants will

\footnotetext{
${ }^{8}$ EU recommends that interconnection capacity should represent at least $10 \%$ of peak demand of the smaller interconnected system.
} 
Table 3

Expected variation in ordinary regime capacities in Portugal mainland, 2011-2020.

\begin{tabular}{|c|c|c|c|c|c|c|}
\hline Year & Company & Location & Fuel & $\begin{array}{l}\text { New capacity } \\
\text { (MW) }\end{array}$ & $\begin{array}{l}\text { Decom. capacity } \\
\text { (MW) }\end{array}$ & $\begin{array}{l}\text { Accumulated } \\
\text { variation (MW) }\end{array}$ \\
\hline 2011 & EDP & Carregado & Fuel oil & & 474 & -474 \\
\hline 2011 & EDP & Carregado & Fuel oil/GN & & 236 & -875 \\
\hline 2011 & Elecgás & Pego (II) & CCGT & 417 & & -458 \\
\hline 2011 & EDP & Picote II & Hydro (RR) & 246 & & -212 \\
\hline 2011 & EDP & Bemposta II & Hydro (RR) & 191 & & -21 \\
\hline 2012 & EDP & Setúbal & Fuel oil & & 946 & -960 \\
\hline 2012 & EDP & Alqueva II & Hydro (PS) & 256 & & -712 \\
\hline 2013 & Galp & Sines (I e II) & CCGT & 830 & & 118 \\
\hline 2014 & EDP & Baixo Sabor & Hydro (PS) & 171 & & 289 \\
\hline 2014 & EDP & Ribeiradio/Ermida & Hydro (RR) & 77 & & 366 \\
\hline 2015 & EDP & Foz Tua & Hydro (PS) & 251 & & 617 \\
\hline 2015 & EDP & Venda Nova III & Hydro (PS) & 736 & & 1.353 \\
\hline 2015 & Endesa & Girabolhos + Bogueira & Hydro (PS+RR) & 365 & & 1.718 \\
\hline 2015 & EDP & Alvito & Hydro (PS) & 225 & & 1.943 \\
\hline 2016 & EDP & Fridão & Hydro (RR) & 238 & & 2.388 \\
\hline 2016 & Iberdrola & Gouvães & Hydro (PS) & 880 & & 3.268 \\
\hline 2016 & Iberdrola & Alto Tâmega & Hydro (RR) & 160 & & 3.428 \\
\hline 2016 & Iberdrola & Daivães & Hydro (RR) & 114 & & 3.542 \\
\hline 2017 & Iberdrola & Lavos (I e II) & CCGT & 830 & & 4.372 \\
\hline 2017 & EDP & Sines & Coal & & 1.180 & 3.192 \\
\hline 2018 & EDP & Paradela $I^{\mathrm{a}}$ & Hydro (PS) & 320 & & 3.512 \\
\hline 2020 & EDP & Carvão-Ribeira $^{\mathrm{a}}$ & Hydro (PS) & 555 & & 4.067 \\
\hline \multicolumn{4}{|c|}{ Total with entering foreseen $2011-2020$} & 7.069 & 3.002 & 4.067 \\
\hline
\end{tabular}

RR, run of river; PS, pump-storage.

a Currently under study by the promoter. No license to build has been yet been assigned by the authority (DGEG) nor an agreement has been made for grid connection.

Table 4

Technology roadmap for SR capacity in 2020 and SR installed capacity in 2010.

\begin{tabular}{|c|c|c|c|c|c|c|c|c|c|c|c|}
\hline Technology capacity (MW) & Wind onsh & Wind offsh & Biomass & Biogas & CHP RES & Waves & Conc. solar & Solar PV & Geo. $^{a}$ & Small hydro & Other CHP \\
\hline Target $2020^{\mathrm{b}}$ & 6.800 & 75 & 250 & 142 & 560 & 250 & 500 & 1.000 & 75 & 750 & 1.690 \\
\hline End of 2010 & 3.853 & 0 & 110 & 29 & 348 & 0 & 0 & 122 & 28 & 410 & 1.103 \\
\hline
\end{tabular}

a Refers only to Islands.

b Targets include mainland and both archipelagos.

Table 5

Electricity generation structure in 2010 and in 2020 .

\begin{tabular}{llrllr}
\hline $\mathbf{2 0 1 0}$ & MW & \% & $\mathbf{2 0 2 0}$ & MW & \% \\
\hline Ordinary regime & $\mathbf{1 1 . 9 8 5}$ & $\mathbf{6 7}$ & Ordinary regime & $\mathbf{1 5 . 6 8 4}$ & $\mathbf{5 5}$ \\
Hydro & 4.578 & 26 & Hydro & 9.570 & 34 \\
Thermal & 7.407 & 41 & Thermal & 6.114 & 22 \\
$\quad$ Coal & 1.756 & 10 & Coal & 584 & 2 \\
$\quad$ Fuel/NG and gas oil & 1.822 & 10 & Fuel/NG and gas oil & 0 & 0 \\
$\quad$ Natural gas & 3.829 & 21 & Natural gas & 5.530 & 20 \\
Special regime & $\mathbf{5 . 9 2 3}$ & $\mathbf{3 3}$ & Special regime & $\mathbf{1 2 . 2 1 5}$ & $\mathbf{4 4}$ \\
Other CHP & 1.103 & 6 & Other CHP & 1.690 & 6 \\
RES CHP & 348 & 2 & RES CHP & 560 & 2 \\
Biomass & 110 & 1 & Biomass & 250 & 1 \\
Biogas & 29 & 0 & Biogas & 243 & 1 \\
MSW\&IR & 97 & 1 & MSW\&IR & 97 & 0 \\
Small hydro & 410 & 2 & Small hydro & 750 & 3 \\
Wind onshore & 3.704 & 21 & Wind Onshore & 6.800 & 24 \\
Photovoltaic & 122 & 1 & Photovoltaic & 1.000 & 4 \\
Conc. solar & 0 & 0 & Conc. solar & 500 & 2 \\
Waves & 0 & 0 & Waves & 250 & 1 \\
Wind offshore & 0 & 0 & Wind offshore & 75 & 0 \\
Installed capacity & $\mathbf{1 7 . 9 0 8}$ & & Installed capacity & $\mathbf{2 7 . 8 9 9}$ &
\end{tabular}

a Installed capacity connected to power supply to the public grid or installed thermal power in accordance to M.O. 399/2002. gradually end from 2011 until 2024: Carregado by 2011, Setúbal by 2012, Sines by 2017, Pego by 2021 and Tapada do Outeiro by 2024.

Fig. 7 shows that the contracted CMEC hydro capacity has remained quite constant until 2010, at around $4.094 \mathrm{MW}$ (23\% of total installed capacity), and will remain at this level until 2013. These long-term contracts for conventional large hydro plants will gradually end between 2013 and 2024 and more abruptly between 2025 and 2027: Miranda, Bemposta and Picote by 2013, Fratel, Alto Rabagão, Bouçã, Caniçada, Cabril, Salamonde, Castelo de Bode and Vila Nova-Paradela by 2015, Vilarinho das Furnas by 2022, Caldeirão, Touvedo, Pracana, Alto Lindoso, Torrão, Crestuma/Lever, Pocinho, Raiva, Aguieira, Valeira, Régua, Carrapatelo, Vilar-Tabuaço by 2024 and Vila Nova-Venda Nova and Frades by 2027.

It can be found from Fig. 8 that SR contracted capacity has been continuously increasing until 2010, when it represented 6.095 MW (34\% of total installed capacity) and it is expected to exhibit a peak by 2020 , when it will reach $12.220 \mathrm{MW}$ (44\% of total installed capacity). In 2020 several generators' price guarantees come to an end: in wind generation circa $1.000 \mathrm{MW}$; in MWs all contracted capacity; in biomass and biogas a few MWs. The continuous decrease in SR contracted capacity between 2020 and 2030 is mostly due to wind contracts. In 2030, 6.390 MW 


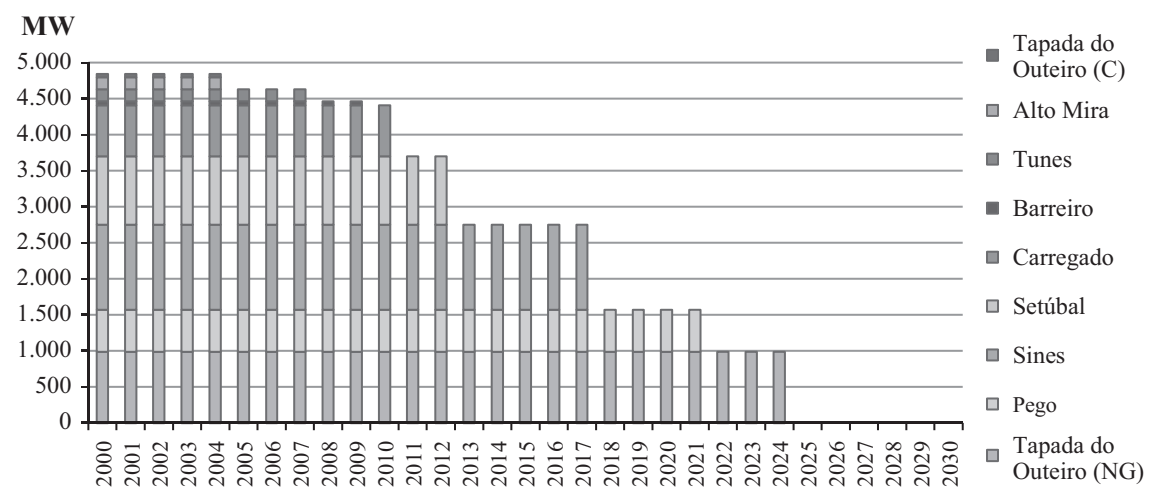

Fig. 6. CMEC/PPA contracted capacity thermal power plants.

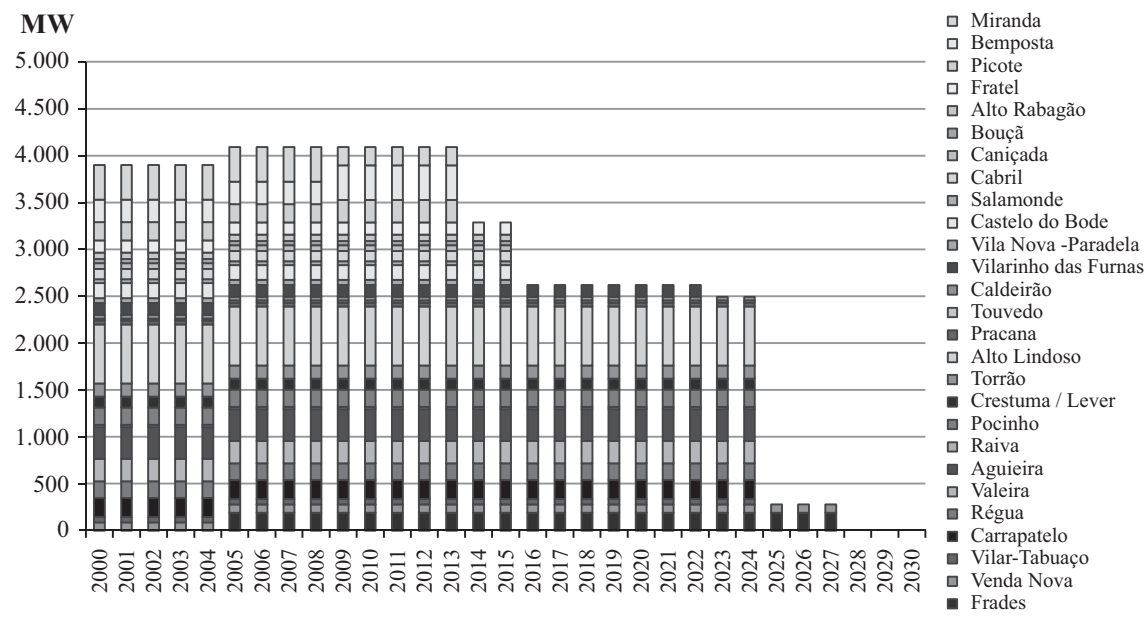

Fig. 7. CMEC contracted capacity hydro power plants.

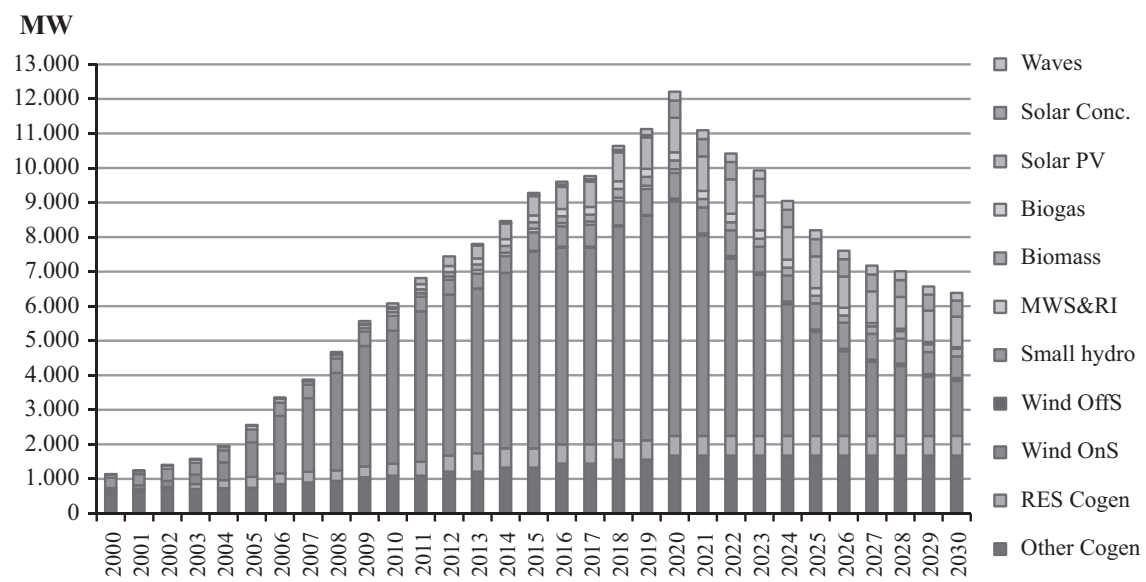

Fig. 8. Special regime contracted capacity as known at the end of 2010.

installed capacity will still benefit from State guaranteed prices: $2.250 \mathrm{MW}$ CHP (35\% of that year total contracted capacity), $1.603 \mathrm{MW}$ wind capacity (25\%), $890 \mathrm{MW}$ solar PV (14\%); $628 \mathrm{MW}$ small hydro (10\%), $460 \mathrm{MW}$ concentrated solar (7\%), $219 \mathrm{MW}$ biomass (3\%), $215 \mathrm{MW}$ waves (3\%) and $75 \mathrm{MW}$ wind offshore (1\%).

The sum of the previous three figures results in Fig. 9, which represents the total amount of contracted price-guaranteed capacity until 2030. As can be seen there, contracted capacities peak in 2020 at 16.547 MW. Continuous decreases in PPA and CMECs are observed from 2010 up to 2024. From 2025 to 2030, contracted capacity is mostly SR.

\subsection{Production volumes}

Yearly data is available for operating units connected to the public grid during the period 2000-2010, both OR and SR. For OR producers, in the period 2000-2010, aggregated data was collected for PPA and CMEC productions ${ }^{9}$ [27-31], as well as individual data for all thermal operating units (PPA/CMEC and new power plants) $[26,45]$. For SR producers, in the period 2000-2010, aggregated

\footnotetext{
${ }^{9}$ From 2000 to 2009 verified productions were considered. For 2010, estimated production was considered.
} 
Table 6

Duration of renewable and waste feed-in tariffs according to applicable legislation.

\begin{tabular}{|c|c|c|c|c|c|c|c|c|c|c|}
\hline \multirow{2}{*}{ Wind OnS } & \multicolumn{2}{|c|}{$\begin{array}{l}\text { DL } 339-C / 2001 \\
2001\end{array}$} & \multicolumn{2}{|c|}{$\begin{array}{l}\text { DL 33-A/2005 } \\
2005\end{array}$} & \multicolumn{2}{|c|}{$\begin{array}{l}\text { DL 225/2007 } \\
2007\end{array}$} & \multicolumn{2}{|c|}{$\begin{array}{l}\text { DL } 126 / 2010 \\
\text { MO 1057/2010 } \\
\text { DL 132-A/2010 } \\
\text { Tenders } \\
2010\end{array}$} & \multicolumn{2}{|c|}{$\begin{array}{l}\text { Future } \\
2010 \ldots 2020\end{array}$} \\
\hline & $15^{\mathrm{a}}$ & Years & 15 & Years & 15 & Years & $14^{\mathrm{c}}$ & Years & 14 & Years \\
\hline Small hydro & $35^{\mathrm{b}}$ & Years & - & Years & - & Years & 25 & Years & 25 & Years \\
\hline Biomass & $15^{\mathrm{a}}$ & Years & 15 & Years & 25 & Years & 25 & Years & 25 & Years \\
\hline Biogas & $15^{\mathrm{a}}$ & Years & - & Years & 15 & Years & - & Years & 15 & Years \\
\hline MWS & $15^{\mathrm{a}}$ & Years & - & Years & - & Years & - & Years & 15 & Years \\
\hline PV & 15 & Years & 15 & Years & 15 & Years & 20 & Years & 15 & Years \\
\hline CSolar $^{\mathrm{d}}$ & - & Years & - & Years & - & Years & $12 / 15$ & Years & $12 / 15$ & Years \\
\hline Waves & - & Years & - & Years & - & Years & 15 & Years & 15 & Years \\
\hline Wind OffS & - & Years & - & Years & - & Years & 15 & Years & 15 & Years \\
\hline
\end{tabular}

a If the installation began operation before 2005, 15 years are considered from then on.

${ }^{\mathrm{b}}$ If the installation began before 1990, 35 years are counted since 1996.

c 14 years is a simplification which accounts for the $33 \mathrm{G} \mathrm{Wh} / \mathrm{MW}$ of wind production limit (to be entitled to the feed-in tariff), to be attained prior to the 15 years limit by the most recent wind project developments.

d $\mathrm{CSP} / \mathrm{CPV}$.

Table 7

Duration of cogeneration feed-in tariffs.

\begin{tabular}{|c|c|c|c|c|}
\hline \multirow{2}{*}{$\begin{array}{l}- \\
\text { RES CHP }\end{array}$} & \multicolumn{2}{|c|}{$\begin{array}{l}\text { MO } 57 \text { to } 60 / 2002 \\
2002\end{array}$} & \multicolumn{2}{|c|}{$\begin{array}{l}\text { DL } 23 / 2010^{\mathrm{a}} \\
-2010 \ldots 2020\end{array}$} \\
\hline & $\mathrm{nd}^{\mathrm{b}}$ & Years & 25 & Years \\
\hline Other CHP & $n d^{c}$ & Years & 25 & Years \\
\hline
\end{tabular}

a DL 23/2010 anticipates that production is integrated directly into the market and receives a premium, though these premiums have not yet been defined.

${ }^{\mathrm{b}}$ No defined end limit.

${ }^{c}$ No defined end limit, despite a 50\% reduction in the environmental parcel 10 years after the beginning of operation.

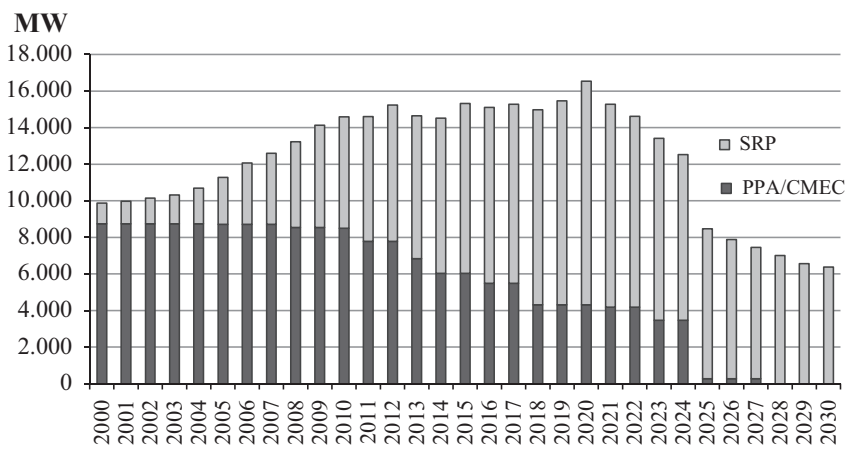

Fig. 9. Total CMEC/PPA and SR contracted capacity.

data was collected [25,37]. For some SR producers, data was collected individually within the whole period 2000-2010 from several institutional and private sources (DGEG, INEGI, APREN, COGEN Portugal, EDP, Valorsul) and organized into a consistent SR producers' dataset, because no such public dataset exists in Portugal. Each data source uses its own methodology and not all sources provide individual data. Individual actual SR production data used represents $32 \%$ of total production in the case of wind; $24 \%$ in the case of small hydro; $3 \%$ in the case of photovoltaic; $35 \%$ in the case of biomass; $0 \%$ in the case of biogas; $100 \%$ in the case of MWS; $9 \%$ in the case of RES CHP; and 0\% in the case of Other CHP. When yearly individual production data was not available, it was estimated considering the unit's installed capacity and the
Table 8

Generation scenarios.

\begin{tabular}{lll}
\hline Assumptions & OR historical average & OR 2006 \\
\hline SR minimum & Generation Scenario 1 & Generation Scenario 3 \\
SR maximum & Generation Scenario 2 & Generation Scenario 4 \\
\hline
\end{tabular}

"OR historical average" where production of large hydro plants is historical (1956- 1995) average and production of thermal plants is average of the last 11 years (2000-2010); “OR 2006“" where production of both large hydro and thermal plants is identical with 2006 values (this year had $\mathrm{PHI}=0.98$, therefore very close to average hydro producibility); "SR minimum" corresponding to low SR capacity utilization factors; and, "SR maximum" corresponding to high SR capacity utilization factors.

historical annual production per technology as described in Eq. (1).

$P_{i a}=\left(T P_{a}-T P_{k a}\right) \times \frac{C_{i a}}{T C_{i a}} \times F_{w}$

$P_{i a}$ corresponds to production volume of installation $i$ in year $a$.

$T P_{a}$ corresponds to total production volume during year $a$.

$T P_{k a}$ corresponds to total production volume of installations $(k)$ with known yearly individual production.

$C_{i a}$ corresponds to installed capacity of installation $i$ in year $a$.

$T C_{i a}$ corresponds to total installed capacity among installations

(i) with unknown yearly individual productions in year $a$.

$F_{w}$ is a factor to account for the simplification used in accounting an annual periodicity of feed-in tariffs instead of the due monthly one. This value was assumed $\frac{1}{3}$ and $\frac{2}{3}$ in the first and later years to account for the fact that most wind farms start operation by $\mathrm{mid} / \mathrm{end}$ of year. For all other cases it was assumed 0.5.

For the period 2011-2030, yearly production volumes have been estimated for four different scenarios. Each scenario corresponds to different assumptions concerning both OR and SR production, as shown in Table 8 .

SR scenarios have been built considering historical capacity utilization factors (CUF) from two sources, in the period 2000$2010[25,46]$ and expected CUF from two other sources, in the period 2010-2020 [42,43]. The CUF represents the number of hours the plant should have operated at full capacity relative to the $8760 \mathrm{~h}$ of the year, in order to deliver the actual yearly output. These CUFs can be found in Appendix B.

CUFs in "SR minimum" scenario are expressed in Table 9, while Table 10 represents CUFs in "SR maximum" scenario. "SR minimum" scenario considers, for each year of the period 2011-2030, the lowest of the maximum CUF values from all four analyzed 
Table 9

Capacity utilization factors per technology in "SR minimum" scenario.

\begin{tabular}{|c|c|c|c|c|c|c|c|c|c|c|}
\hline CUF (\%) & 2011 & 2012 & 2013 & 2014 & 2015 & 2016 & 2017 & 2018 & 2019 & 2020-2030 \\
\hline Wind OnS & 26.7 & 26.7 & 26.7 & 26.7 & 26.7 & 26.7 & 26.7 & 26.7 & 26.7 & 26.7 \\
\hline Small hydro & 23 & 23 & 23 & 23 & 23 & 23 & 23 & 23 & 23 & 23 \\
\hline Biomass & 47.1 & 47.1 & 47.1 & 47.1 & 47.1 & 47.1 & 47.1 & 47.1 & 47.1 & 47.1 \\
\hline MWS & 64.4 & 64.4 & 64.4 & 64.4 & 64.4 & 64.4 & 64.4 & 64.4 & 64.4 & 64.4 \\
\hline Biogas & 40 & 40 & 40 & 40 & 40 & 40 & 40 & 40 & 40 & 40 \\
\hline PV & 17.2 & 17.2 & 17.2 & 17.2 & 17.2 & 17.2 & 17.2 & 17.2 & 17.2 & 17.2 \\
\hline Conc. Solar & 22.8 & 22.8 & 22.8 & 22.8 & 22.8 & 22.8 & 22.8 & 22.8 & 22.8 & 22.8 \\
\hline RES CHP & 40.1 & 40.1 & 40.1 & 40.1 & 40.1 & 40.1 & 40.1 & 40.1 & 40.1 & 40.1 \\
\hline Other CHP & 46 & 46 & 46 & 46 & 46 & 46 & 46 & 46 & 46 & 46 \\
\hline Waves & 4.6 & 6.9 & 10.3 & 11.4 & 14.3 & 17.1 & 18.2 & 18.8 & 19.4 & 20 \\
\hline Wind OffS & ne & ne & ne & ne & 27.4 & 27.4 & 27.4 & 27.4 & 27.4 & 27.4 \\
\hline
\end{tabular}

Table 10

Capacity utilization factors per technology in "SR maximum" scenario.

\begin{tabular}{|c|c|c|c|c|c|c|c|c|c|c|}
\hline CUF (\%) & 2011 & 2012 & 2013 & 2014 & 2015 & 2016 & 2017 & 2018 & 2019 & 2020-2030 \\
\hline Wind OnS & 28.2 & 28.2 & 28.2 & 28.2 & 28.2 & 28.2 & 28.2 & 28.2 & 28.2 & 28.2 \\
\hline Small hydro & 38.8 & 38.8 & 38.8 & 38.8 & 38.8 & 38.8 & 38.8 & 38.8 & 38.8 & 38.8 \\
\hline Biomass & 75.7 & 75.7 & 75.7 & 75.7 & 75.7 & 75.7 & 75.7 & 75.7 & 75.7 & 75.7 \\
\hline MWS & 76.5 & 76.5 & 76.5 & 76.5 & 76.5 & 76.5 & 76.5 & 76.5 & 76.5 & 76.5 \\
\hline Biogas & 79.9 & 79.9 & 79.9 & 79.9 & 79.9 & 79.9 & 79.9 & 79.9 & 79.9 & 79.9 \\
\hline PV & 23.1 & 23.1 & 23.1 & 23.1 & 23.1 & 23.1 & 23.1 & 23.1 & 23.1 & 23.1 \\
\hline Conc. solar & 22.8 & 22.8 & 22.8 & 22.8 & 22.8 & 22.8 & 22.8 & 22.8 & 22.8 & 22.8 \\
\hline RES CHP & 63.9 & 63.9 & 63.9 & 63.9 & 63.9 & 63.9 & 63.9 & 63.9 & 63.9 & 63.9 \\
\hline Other CHP & 46 & 46 & 46 & 46 & 46 & 46 & 46 & 46 & 46 & 46 \\
\hline Waves & 3.4 & 5.7 & 5.7 & 11.4 & 14.8 & 14.3 & 20 & 20 & 28.6 & 28.6 \\
\hline Wind OffS & ne & 11.4 & 17.2 & 22.8 & 26.7 & 26.3 & 29.7 & 29.7 & 29.7 & 29.7 \\
\hline
\end{tabular}

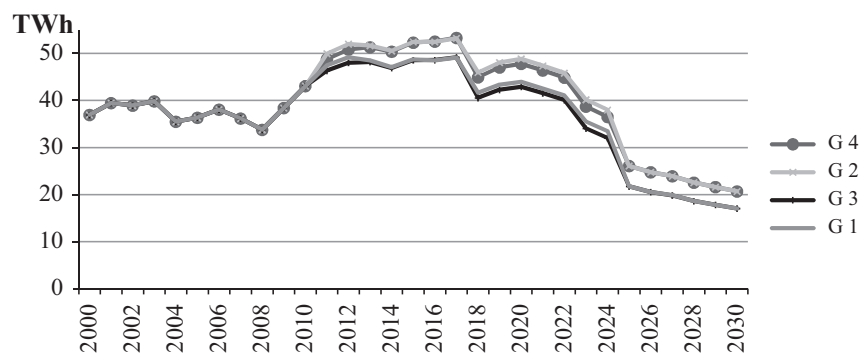

Fig. 10. Electricity generation with State guaranteed prices-all considered scenarios.

sources, for existing SR technologies (more mature technologies). For new SR technologies (less mature technologies) such as concentrated solar, waves and wind offshore, each year's CUF was considered as in the source with the lowest CUF values for that technology. "SR maximum" scenario results from the major of the maximum encountered CUFs values from these four sources for already existing SR technologies. For new SR technologies, each year's CUF was considered as in the source with the higher CUF values for that technology. As technological performance tends to improve with time, it may be assumed that "SR minimum" scenario represents one of the lowest possible case scenarios for expected SR production in the future. The production volumes associated with each plant type and each generation scenario are presented in Appendix C for the period 2000-2030.

Based on the above assumptions and generation scenarios it is possible to calculate the amount of electricity generated every year by all producers with State guaranteed prices. Fig. 10 shows the results of these calculations. It can be seen that Generation Scenario 3 is the case where the sum of all contracted electricity in the period 2011-2030 is lower, while Generation Scenario 2 is the case where the sum of all contracted electricity in that period is higher.
The two extreme scenarios will be further analyzed in the following section. It should be pointed out that the amounts of electricity generation described in Fig. 10 correspond to State guaranteed prices. As soon as the CMEC, PPA or feed-in tariff of a given power plant ends, the corresponding generation volume is removed from the calculation. This does not mean, however, that the concerned power plant stops production-it just means that the production does not benefit from a State guaranteed price anymore.

\section{How much room for a competitive market until 2030 ?}

The potential for a competitive, free (i.e. without State guaranteed prices) electricity wholesale market can be identified by combining the estimated contracted generation volumes, computed according to the criteria described in Section 5.2 and depicted in Fig. 10, with estimates of the future evolution of electricity demand. Two different demand scenarios have been considered $[24,26,47,48]$ :

- Demand Scenario 1: considers an annual growth rate of $2.2 \%$ in $2011,2.1 \%$ in the period $2012-2020$ and $0.8 \%$ in the period 2021-2030 (annual average of 1.4\%).

- Demand Scenario 2: considers an annual growth rate of $2.2 \%$ in $2011,2.9 \%$ in the period $2012-2020$ and $1.1 \%$ in the period 2021-2030 (annual average 2\%).

The resulting values for electricity demand are graphically represented by the two thick lines on top of Fig. 11. Furthermore, Fig. 11 shows the expected minimum total amount of electricity generation with State guaranteed prices during the period 20002030 (Generation Scenario 3 of Section 5.2, Fig. 10). These amounts consistently decline from 2020 on. 


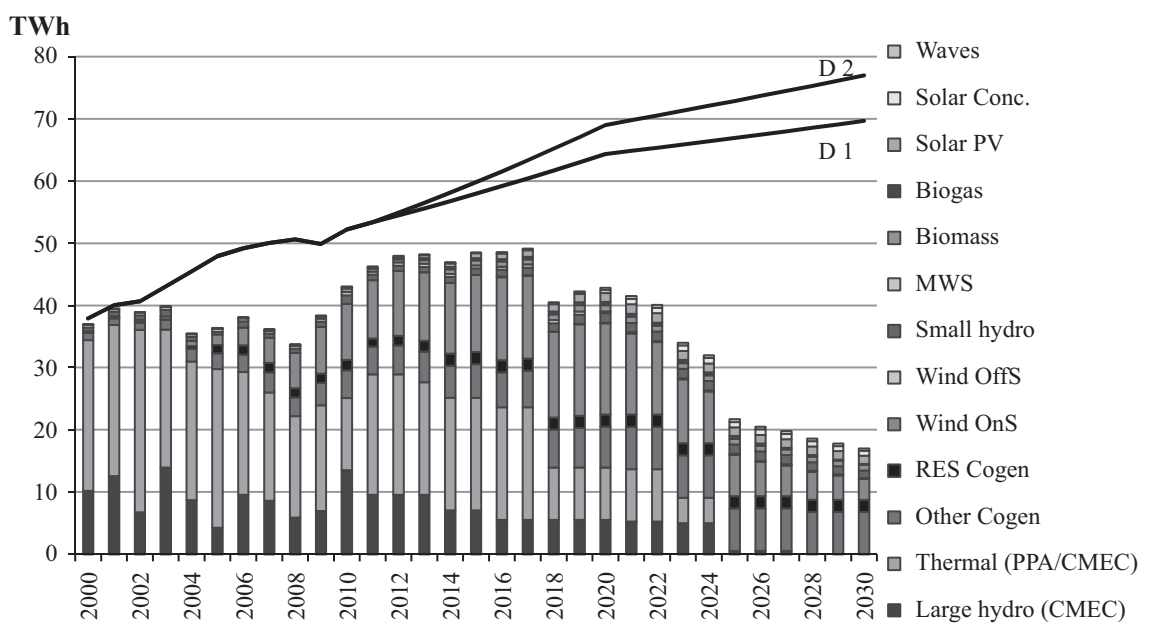

Fig. 11. PPA/CMEC/SR production in Generation Scenario 3, Demand Scenarios 1 and 2.

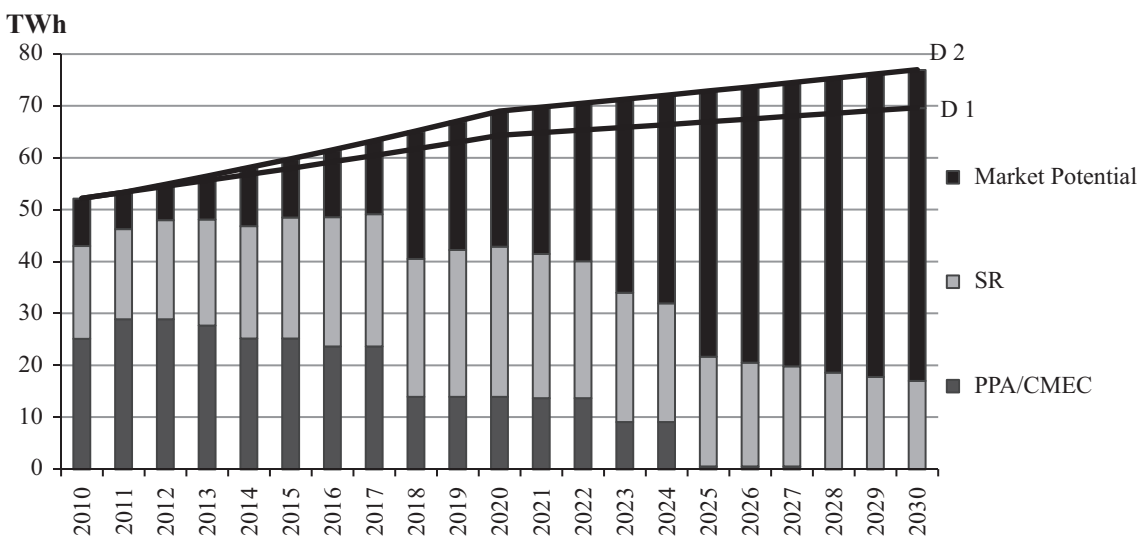

Fig. 12. Market potential in Generation Scenario 3 in the period 2010-2030.

\subsection{Market potential (assuming no impact of State guaranteed price plants once guarantees expire)}

The gap between demand and all generation paid through PPA, CMECs and feed-in tariffs, in the period 2011-2030, as described in Fig. 12, represents the expected market potential. Similarly to what has been shown in Table 1 (in Section 2), the market potential includes all the expected OR production other than PPA/CMECs and imports balance net of hydro pumping. Fig. 13 shows the relative size of the expected market potential from 2000 to 2030, for both the lowest and the highest scenarios computed in Section 5.2 (Generation Scenarios 3 and 2, respectively). In 2010, the market potential represented $17 \%$ of total demand (final consumption plus network losses). One has to wait until 2018 to reach 33\%, until 2024 to reach 50\% and until 2030 to reach $75 \%$, considering the lowest generation scenario. These periods are extended up to 2023 to reach 33\%, until 2025 to reach $50 \%$ and until after 2030 to reach $75 \%$ when considering the highest generation scenario. Tables D1 and D2 show further detail on the market potential in these scenarios.

\subsection{Revised market potential (considering the impact of State guaranteed price plants after guarantees have expired)}

In the previous Section 6.1 it was assumed that, for each power plant, at the end of the guaranteed price period, the respective capacity would vanish, making room for a competitive wholesale market. However, in most cases the lifetime of these power plants goes well beyond the duration of the guaranteed price regime. Although these plants may have to compete in the market, since they do not benefit from State guaranteed prices anymore, it is less obvious that they will make room for new entrants. Coal fired generation has an average lifetime of $40-50$ years before the plants become technically obsolete. For gas and oil-fired generation, the average technical lifetime is about 40 years. Furthermore, when economically interesting and technically feasible, the lifetime of some plants can be easily extended beyond these ranges by replacing specific parts. Wind farms have expected lifetimes of 25 years and more. Because at the end of the guaranteed price period the power plants are almost fully depreciated and, in most cases (particularly for renewable plants, including large hydro), their variable costs are very low, these units will keep running, effectively pre-emptying the entry of new power plants.

Assuming that - (a) all renewable capacities built until 2020, both SR and OR, are available until 2030; (b) all currently operating thermal power plants will keep running until 2030 (except Tunes, Carregado and Setúbal); and (c) a priority merit order of dispatch is applied to all renewable plants, followed by all PPA/CMEC contracted generation - the market potential evolution is much lower than indicated in Figs. 12 and 13. Appendix E presents the volumes of electricity generation by technology in the period 2000-2030, from those producers who have or have had a guaranteed price, under all generation scenarios analyzed in Section 5.2, taking into account the three above mentioned assumptions. Fig. 14 depicts the revised market potential 


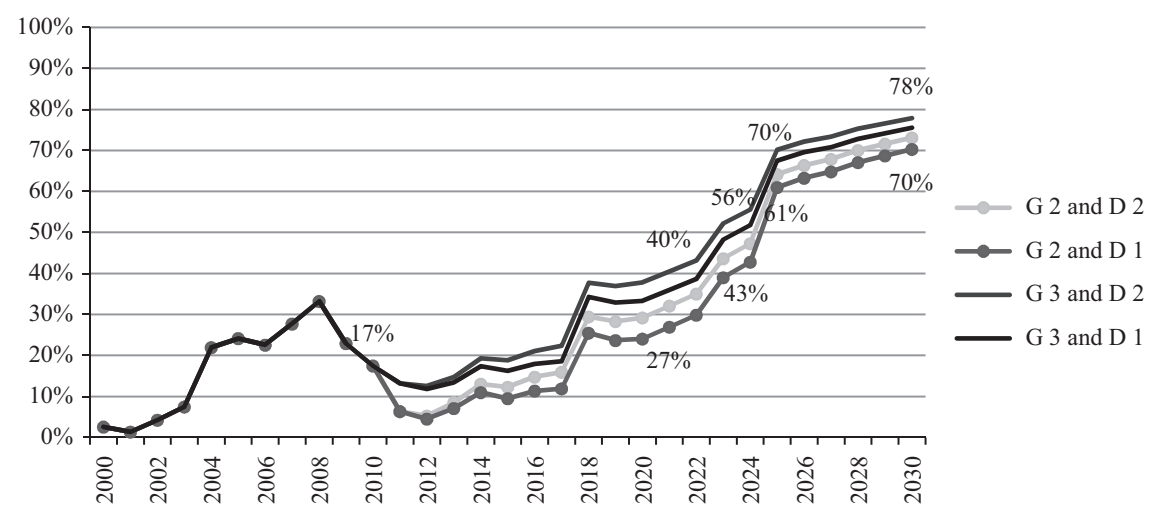

Fig. 13. Market potential in Generation Scenarios 2 and 3, Demand Scenarios 1 and 2.

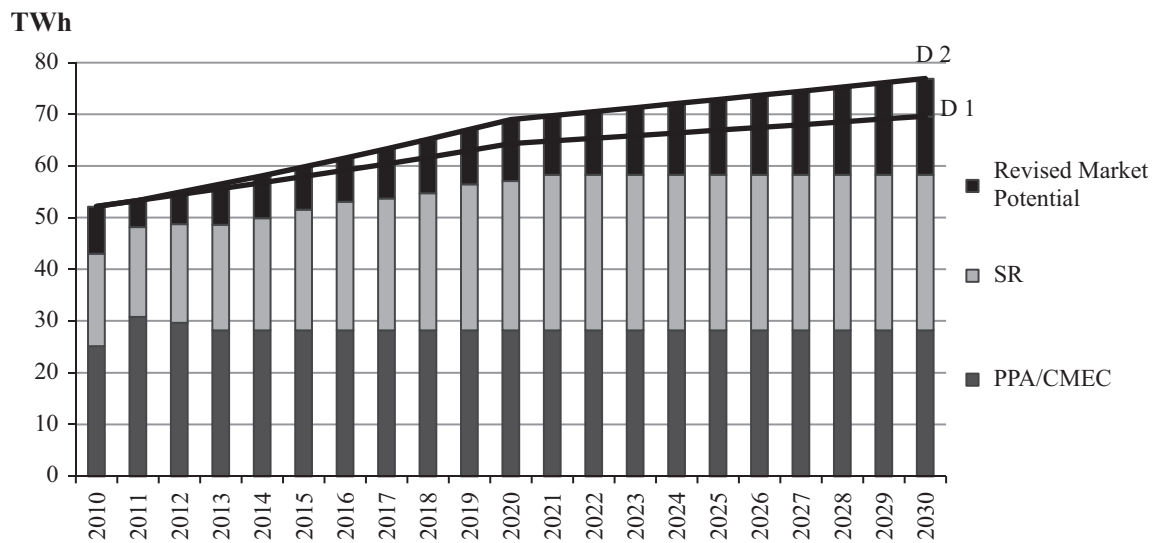

Fig. 14. Revised market potential in Generation Scenario 3 in the period 2010-2030 taking into account existing capacities after price guarantees expire.

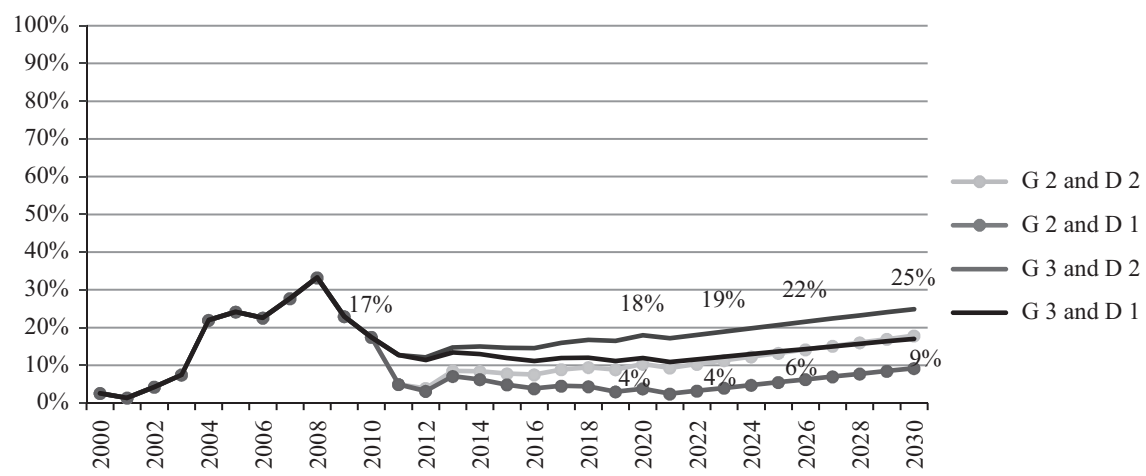

Fig. 15. Revised market potential for Generation Scenarios 2 and 3 combined with Demand Scenarios 1 and 2.

for the lowest generation scenario (Generation Scenario 3) and the two demand scenarios.

The relative importance of the revised market potential to electricity demand is represented in Fig. 15 for the period 2000-2030, related to both the lowest and the highest generation scenarios. The revised market potential in the lowest generation scenario could be covered by CCGT plants. Considering a utilization factor of $85 \%$ for each CCGT plant, this coveraged could be ensured by the Ribatejo CCGT until 2025, in the lower demand scenario, and until 2016, in the higher demand scenario; by Ribatejo and Lares CCGTs until after 2030, in the lower demand scenario, and until 2025, in the higher demand scenario; by Ribatejo, Lares and Pego II units until after 2030, in both the demand scenarios. Tables F1 and F2 show further detail about the revised market potential under these scenarios.

\subsection{Market and policy challenges ahead}

The illustrative analysis introduced in the previous sections is based on average yearly production values and as such gives no accurate inference regarding system reliability and security of supply. It does not account for operational reserves neither for capacity needed to cover peak demand evolution. Nevertheless, it provides interesting insights concerning the eventual need for new capacity to satisfy the expected future demand. Figs. 12-15 (Sections 6.1 and 6.2) show that there is indeed very limited room for new generation plants other than CCGT in the Portuguese electricity system, beyond what has already been granted or is already planned, to cover expected average demand growth. This does not mean, however, that given the increasing role to be played by intermittent generation (wind and solar) more flexibility will not require new investments also in new conventional 
capacity (among other resources such as demand participation, smart grids, storage or interconnections) most of which will not happen unless the proper incentives are in place. The impact of high penetration of renewable electricity with low or zero marginal costs in the wholesale market means that spot prices decrease and may remain low for longer time periods. This reduces the revenues of all generators, including those needed to ensure sufficient capacity to meet demand when wind and solar are not available.

Table B1

CUF REN.

\begin{tabular}{|c|c|c|c|c|c|c|c|c|c|c|c|}
\hline CUF (\%) & 2000 & 2001 & 2002 & 2003 & 2004 & 2005 & 2006 & 2007 & 2008 & 2009 & 2010 \\
\hline Wind OnS & 21.5 & 23 & 21.6 & 19.3 & 16.7 & 19.9 & 20 & 21.4 & 23.6 & 24.3 & 26.7 \\
\hline Small hydro & 32.2 & 34.6 & 26.9 & 38.8 & 24.5 & 13.8 & 31.4 & 21.7 & 20.2 & 23.8 & 38.4 \\
\hline Biomass & 7.41 & 22.3 & 42.4 & 46.4 & 58.1 & 58.8 & 33.1 & 69 & 62.8 & 33.7 & 63.3 \\
\hline MWS & 61 & 60.4 & 61.3 & 62.3 & 56.4 & 64.4 & 62.9 & 58.2 & 60.3 & 62.5 & 62.1 \\
\hline Biogas & 1.5 & 2.97 & 2.87 & 2.51 & 24.7 & 60.2 & 55.5 & 46.7 & 45.9 & 39.7 & 35.8 \\
\hline PV & 0 & 2.05 & 0 & 0.4 & 7.35 & 4.55 & 456 & 17.2 & 7.28 & 16.7 & 15.6 \\
\hline Conc. solar & ne & ne & ne & ne & ne & ne & ne & ne & ne & ne & ne \\
\hline RES cogen & 16 & 18.9 & 20.1 & 10.1 & 21.1 & 47.8 & 54 & 56.1 & 54.6 & 54.9 & 55.2 \\
\hline Other cogen & 28.8 & 26 & 25.4 & 29.8 & 36.1 & 43.6 & 41.8 & 45.6 & 36.8 & 38.4 & 46 \\
\hline Waves & ne & ne & ne & ne & ne & ne & ne & ne & ne & ne & ne \\
\hline Wind OffS & ne & ne & ne & ne & ne & ne & ne & ne & ne & ne & ne \\
\hline
\end{tabular}

Table B2

CUF DGEG.

\begin{tabular}{|c|c|c|c|c|c|c|c|c|c|c|c|}
\hline CUF (\%) & 2000 & 2001 & 2002 & 2003 & 2004 & 2005 & 2006 & 2007 & 2008 & 2009 & 2010 \\
\hline Wind OnS & 25.4 & 28.2 & 27.8 & 26.2 & 25.5 & 26.3 & 24.2 & 23.6 & 26 & 25.5 & 27.4 \\
\hline Small hydro & 29.9 & 31.6 & 26.3 & 34 & 21.4 & 11.2 & 28.8 & 17.4 & 16.8 & 19.5 & 30.2 \\
\hline Biomass & ne & 30.6 & 59.9 & 61.4 & 49.5 & 60.9 & 75.7 & 70.9 & 69.4 & 70.5 & 67.5 \\
\hline MWS & 66.7 & 66.3 & 67.2 & 67.8 & 61.6 & 70.7 & 69 & 64.6 & 57.2 & 59.4 & 59 \\
\hline Biogas & 18.6 & 24.7 & 28.5 & 26.3 & 22.5 & 43.2 & 45.9 & 50.6 & 61.7 & 53.5 & 51.5 \\
\hline PV & 13.6 & 13.6 & 13.7 & 14.1 & 12.4 & 14.9 & 13.6 & 18.6 & 18.5 & 22.9 & 23.1 \\
\hline Conc. solar & ne & ne & ne & ne & ne & ne & ne & ne & ne & ne & ne \\
\hline RES cogen & 34.2 & 35.3 & 35.8 & 34.7 & 38.6 & 41.1 & 41.6 & 43.5 & 44.2 & 44.3 & 50.1 \\
\hline Other cogen & na & na & na & na & na & na & na & na & na & na & na \\
\hline Waves & ne & ne & ne & ne & ne & ne & ne & ne & ne & ne & ne \\
\hline Wind OffS & ne & ne & ne & ne & ne & ne & ne & ne & ne & ne & ne \\
\hline
\end{tabular}

Table B3

CUF NREAP.

\begin{tabular}{|c|c|c|c|c|c|c|c|c|c|c|c|}
\hline CUF (\%) & 2010 & 2011 & 2012 & 2013 & 2014 & 2015 & 2016 & 2017 & 2018 & 2019 & 2020 \\
\hline Wind OnS & 27.4 & 26.3 & 25.7 & 25.7 & 25.7 & 25.1 & 25.1 & 25.1 & 25.1 & 24.2 & 24.2 \\
\hline Small hydro & 23 & 23 & 23 & 23 & 23 & 23 & 23 & 23 & 23 & 23 & 23 \\
\hline Biomass & 47 & 47.1 & 46.4 & 45.1 & 45.8 & 45.8 & 45.5 & 45.5 & 45.3 & 45.3 & 45.1 \\
\hline MWS & ne & ne & ne & ne & ne & ne & ne & ne & ne & ne & ne \\
\hline Biogas & 40 & 39.7 & 40 & 40 & 40 & 40 & 40 & 40 & 40 & 40 & 40 \\
\hline PV & 16.8 & 16.8 & 16.9 & 22.8 & 16.9 & 16.9 & 16.8 & 16.8 & 16.8 & 16.8 & 16.8 \\
\hline Conc. solar & ne & 22.8 & 22.8 & 22.8 & 22.8 & 22.8 & 22.8 & 22.8 & 22.8 & 22.8 & 22.8 \\
\hline RES cogen & 40.1 & 40.1 & 40.1 & 40.1 & 40.1 & 40.1 & 40.1 & 40.1 & 40.1 & 40.1 & 40.1 \\
\hline Other cogen & na & na & na & na & na & na & na & na & na & na & na \\
\hline Waves & 2.28 & 4.57 & 6.85 & 10.3 & 11.4 & 14.3 & 17.1 & 18.2 & 18.8 & 19.4 & 20 \\
\hline Wind OffS & ne & ne & ne & ne & ne & 27.4 & 27.4 & 27.4 & 27.4 & 27.4 & 27.4 \\
\hline
\end{tabular}

Table B4

CUF APREN.

\begin{tabular}{|c|c|c|c|c|c|c|c|c|c|c|c|}
\hline CUF (\%) & 2010 & 2011 & 2012 & 2013 & 2014 & 2015 & 2016 & 2017 & 2018 & 2019 & 2020 \\
\hline Wind OnS & 27.4 & 27.2 & 27 & 26.8 & 26.6 & 26.4 & 26.2 & 26 & 25.7 & 25.5 & 25.1 \\
\hline Small hydro & 29.7 & 29.7 & 29.7 & 29.7 & 29.7 & 29.7 & 29.7 & 29.7 & 29.7 & 29.7 & 29.7 \\
\hline Biomass & 63.9 & 63.9 & 63.9 & 63.9 & 63.9 & 63.9 & 63.9 & 63.9 & 63.9 & 63.9 & 63.9 \\
\hline MWS & 76.5 & 76.5 & 76.5 & 76.5 & 76.5 & 76.5 & 76.5 & 76.5 & 76.5 & 76.5 & 76.5 \\
\hline Biogas & 79.9 & 79.9 & 79.9 & 79.9 & 79.9 & 79.9 & 79.9 & 79.9 & 79.9 & 79.9 & 79.9 \\
\hline PV & 19.4 & 19.4 & 19.4 & 19.4 & 19.4 & 19.4 & 19.4 & 19.4 & 19.4 & 19.4 & 19.4 \\
\hline Conc. solar & 22.8 & 22.8 & 22.8 & 22.8 & 22.8 & 22.8 & 22.8 & 22.8 & 22.8 & 22.8 & 22.8 \\
\hline RES cogen & 63.9 & 63.9 & 63.9 & 63.9 & 63.9 & 63.9 & 63.9 & 63.9 & 63.9 & 63.9 & 63.9 \\
\hline Other cogen & na & na & na & na & na & na & na & na & na & na & na \\
\hline Waves & 3.42 & 3.42 & 5.71 & 5.71 & 11.4 & 14.3 & 14.3 & 20 & 20 & 28.5 & 28.5 \\
\hline Wind OffS & 0 & 0 & 11.4 & 17.1 & 22.8 & 26.3 & 26.3 & 29.7 & 29.7 & 29.7 & 29.7 \\
\hline
\end{tabular}


Moreover, these figures clearly show that the amount of both capacity and generation with guaranteed price is such that there is no significant room for a competitive electricity market for conventional plants, for RES and CHP facilities or for ancillary services until at least 2020. Therefore, only if the appropriate policy measures are undertaken with the mid to long term horizon vision in mind to build a new future electricity system (and not a continuation of the previous paradigm) will this lack of competitiveness most certainly be transitory and consumers may benefit from more efficient prices.

Until 2020, the Portuguese generation system faces two big and related challenges: (1) how to cope with $50 \%$ and more generation from RES (balancing issue) and (2) how to ensure appropriate

Table B5

Comparison of maximum CUF among sources REN/DGEG 2000-2010; PNAER/ APREN 2011-2020.

\begin{tabular}{|c|c|c|c|c|c|c|}
\hline \multirow[t]{2}{*}{ CUF (\%) } & \multicolumn{2}{|c|}{$2011-2020$} & \multicolumn{2}{|c|}{$2000-2010$} & \multicolumn{2}{|c|}{$2011-2020$} \\
\hline & PNAER & APREN & REN & DGEG & SRP min & $\mathrm{SRP} \max$ \\
\hline Wind OnS & 27.4 & 27.4 & 26.7 & 28.2 & 26.7 & 28.2 \\
\hline Small hydro & 23 & 29.7 & 38.8 & 34 & 23 & 38.8 \\
\hline Biomass & 47.1 & 63.9 & 68.9 & 75.7 & 47.1 & 75.7 \\
\hline MWS & ne & 76.5 & 64.4 & 70.7 & 64.4 & 76.5 \\
\hline Biogas & 40 & 79.9 & 60.2 & 61.7 & 40 & 79.9 \\
\hline PV & 22.8 & 19.4 & 17.2 & 23.1 & 17.2 & 23.1 \\
\hline Conc. solar & 22.8 & 22.8 & ne & ne & 22.8 & 22.8 \\
\hline RES cogen & 40.1 & 63.9 & 56.1 & 50.1 & 40.1 & 63.9 \\
\hline Other CHP & na & na & 45.9 & na & 45.9 & 45.9 \\
\hline Waves & 19.9 & 28.5 & ne & ne & 19.9 & 28.5 \\
\hline Wind OffS & 27.4 & 29.7 & ne & ne & 27.4 & 29.7 \\
\hline
\end{tabular}
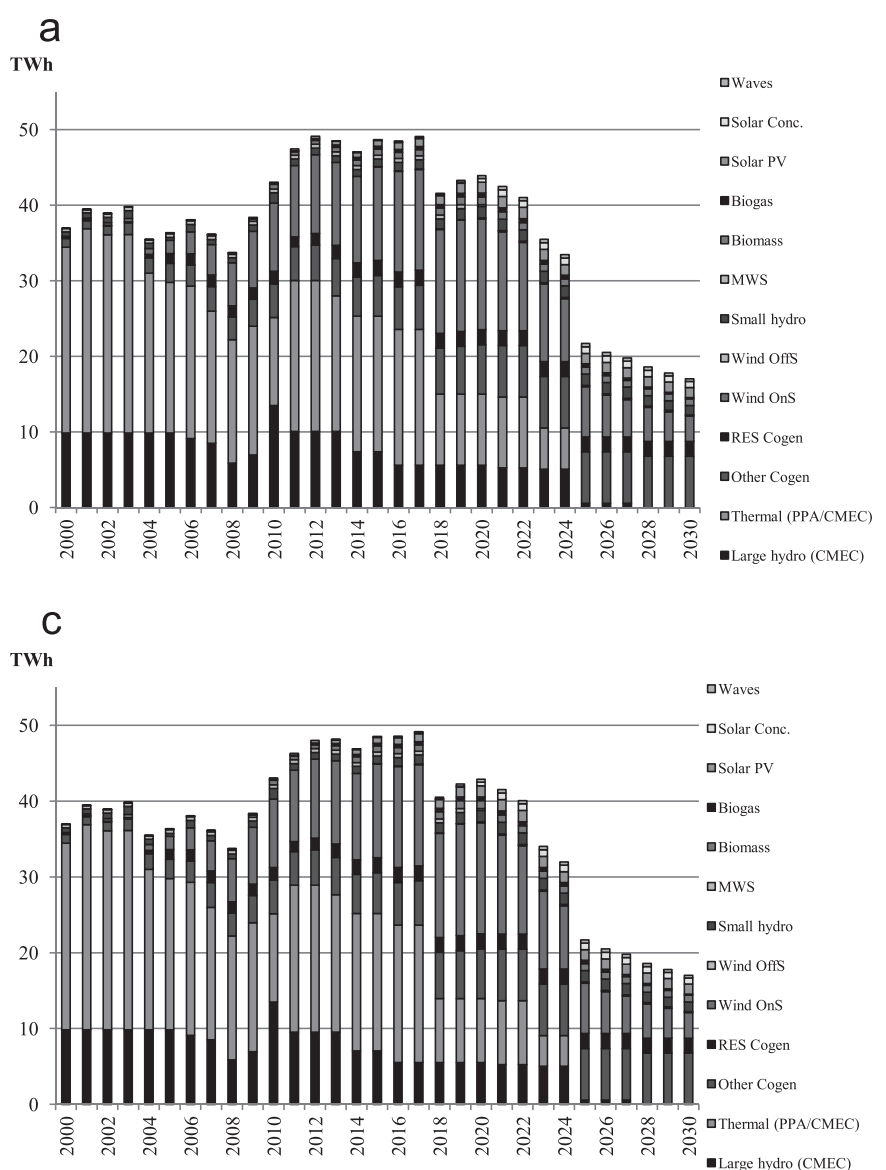

remuneration of power plants needed for capacity/reliability reasons, not necessarily for energy reasons (capacity issue).

After 2020, the Portuguese electricity generation system will face another challenge, namely how to organize a wholesale market where a growing number of plants are fully depreciated and exhibit very low variable costs. To date, the current regulations in place do neither incentivize an active variable renewable electricity or demand side participation in the markets nor an active role in balancing and reserves management. Moreover, these challenges will not be overcome without more innovation and intelligence in the networks at both transmission and distribution levels, in particular through information and communication technologies. Also, barriers to cross-border trade need to be removed because they offer prospects of additional flexibility and efficiency gains. A systematic approach within the Iberian and European frameworks calls for a "New" Regulation so

Table D1

Market potential in Generation Scenario 3.

\begin{tabular}{llllll}
\hline Year & $\begin{array}{l}\text { Demand } \\
(\mathbf{1 . 4 \% )}\end{array}$ & $\begin{array}{l}\text { Demand } \\
(\mathbf{2 \%})\end{array}$ & Year & $\begin{array}{l}\text { Demand } \\
(\mathbf{1 . 4 \% )}\end{array}$ & $\begin{array}{l}\text { Demand } \\
(\mathbf{2 \% )}\end{array}$ \\
\hline $\mathbf{2 0 1 1}$ & $13 \%$ & $13 \%$ & $\mathbf{2 0 2 1}$ & $35 \%$ & $44 \%$ \\
$\mathbf{2 0 1 2}$ & $11 \%$ & $12 \%$ & $\mathbf{2 0 2 2}$ & $38 \%$ & $43 \%$ \\
$\mathbf{2 0 1 3}$ & $13 \%$ & $14 \%$ & $\mathbf{2 0 2 3}$ & $48 \%$ & $52 \%$ \\
$\mathbf{2 0 1 4}$ & $17 \%$ & $19 \%$ & $\mathbf{2 0 2 4}$ & $51 \%$ & $55 \%$ \\
$\mathbf{2 0 1 5}$ & $16 \%$ & $18 \%$ & $\mathbf{2 0 2 5}$ & $67 \%$ & $70 \%$ \\
$\mathbf{2 0 1 6}$ & $17 \%$ & $21 \%$ & $\mathbf{2 0 2 6}$ & $69 \%$ & $72 \%$ \\
$\mathbf{2 0 1 7}$ & $18 \%$ & $22 \%$ & $\mathbf{2 0 2 7}$ & $71 \%$ & $73 \%$ \\
$\mathbf{2 0 1 8}$ & $34 \%$ & $37 \%$ & $\mathbf{2 0 2 8}$ & $73 \%$ & $75 \%$ \\
$\mathbf{2 0 1 9}$ & $32 \%$ & $36 \%$ & $\mathbf{2 0 2 9}$ & $74 \%$ & $77 \%$ \\
$\mathbf{2 0 2 0}$ & $33 \%$ & $37 \%$ & $\mathbf{2 0 3 0}$ & $76 \%$ & $78 \%$ \\
\hline
\end{tabular}

b

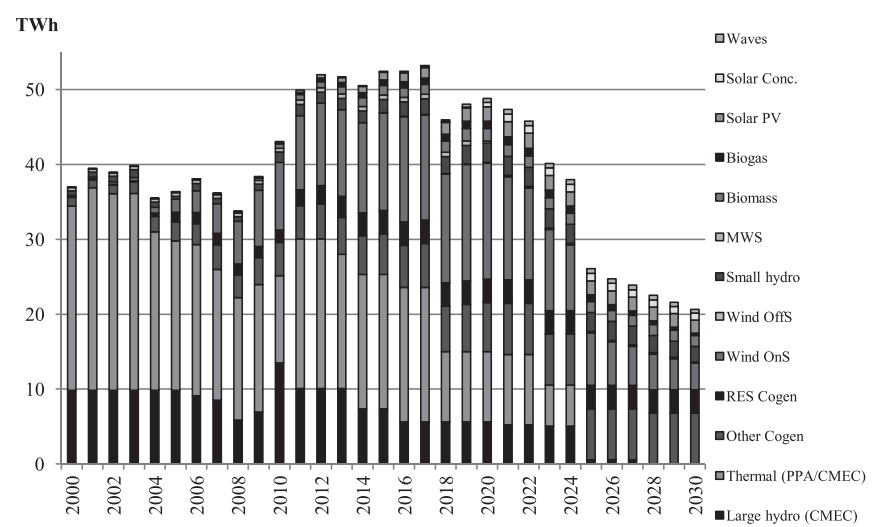

d

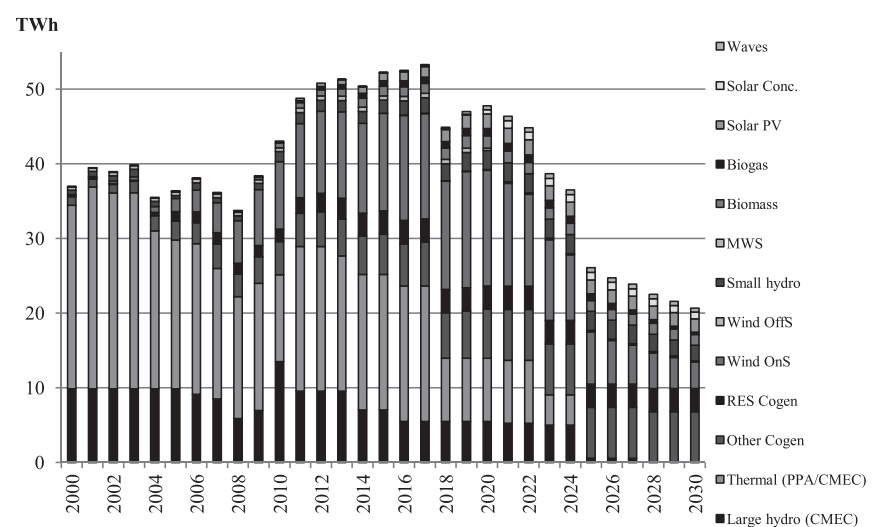

Fig. C1. PPA/CMEC/SR generation: (a) Scenario 1; (b) Scenario 2; (c) Scenario 3; and (d) Scenario 4. 
that the necessary guidelines and incentives are in place to build up a new design for electricity markets, including new grids architectures. Finally, energy policy developments need to take into full account of how each National Electricity System is affected by decisions in neighboring countries. Only working together will keep costs down and ensure security of supply.

\section{Conclusions}

Although the Portuguese electricity system was fully liberalized in 2006 this does not mean that a competitive electricity generation market exists. In fact, in 2010, excluding capacity payments to which conventional producers other than those benefiting from PPA or CMEC regimes are entitled since $2010,83 \%$ of installed electricity generation in Portugal mainland benefited from State guaranteed prices, independently of market conditions.

As shown in this paper, the volume and the duration of the existing legacy contracts prevents the development of a competitive wholesale market at least until the mid 2020s. The

Table D2

Market potential in Generation Scenario 2.

\begin{tabular}{lcllll}
\hline Year & $\begin{array}{l}\text { Demand } \\
(\mathbf{1 . 4 \%})\end{array}$ & $\begin{array}{l}\text { Demand } \\
(\mathbf{2 \%})\end{array}$ & Year & $\begin{array}{l}\text { Demand } \\
(\mathbf{1 . 4 \% )}\end{array}$ & $\begin{array}{l}\text { Demand } \\
(\mathbf{2 \% )})\end{array}$ \\
\hline $\mathbf{2 0 1 1}$ & $6 \%$ & $6 \%$ & $\mathbf{2 0 2 1}$ & $26 \%$ & $31 \%$ \\
$\mathbf{2 0 1 2}$ & $3 \%$ & $4 \%$ & $\mathbf{2 0 2 2}$ & $29 \%$ & $34 \%$ \\
$\mathbf{2 0 1 3}$ & $6 \%$ & $7 \%$ & $\mathbf{2 0 2 3}$ & $38 \%$ & $43 \%$ \\
$\mathbf{2 0 1 4}$ & $10 \%$ & $12 \%$ & $\mathbf{2 0 2 4}$ & $42 \%$ & $46 \%$ \\
$\mathbf{2 0 1 5}$ & $8 \%$ & $11 \%$ & $\mathbf{2 0 2 5}$ & $60 \%$ & $63 \%$ \\
$\mathbf{2 0 1 6}$ & $10 \%$ & $14 \%$ & $\mathbf{2 0 2 6}$ & $63 \%$ & $66 \%$ \\
$\mathbf{2 0 1 7}$ & $11 \%$ & $15 \%$ & $\mathbf{2 0 2 7}$ & $65 \%$ & $68 \%$ \\
$\mathbf{2 0 1 8}$ & $24 \%$ & $28 \%$ & $\mathbf{2 0 2 8}$ & $67 \%$ & $70 \%$ \\
$\mathbf{2 0 1 9}$ & $23 \%$ & $27 \%$ & $\mathbf{2 0 2 9}$ & $69 \%$ & $72 \%$ \\
$\mathbf{2 0 2 0}$ & $23 \%$ & $28 \%$ & $\mathbf{2 0 3 0}$ & $70 \%$ & $73 \%$ \\
\hline
\end{tabular}
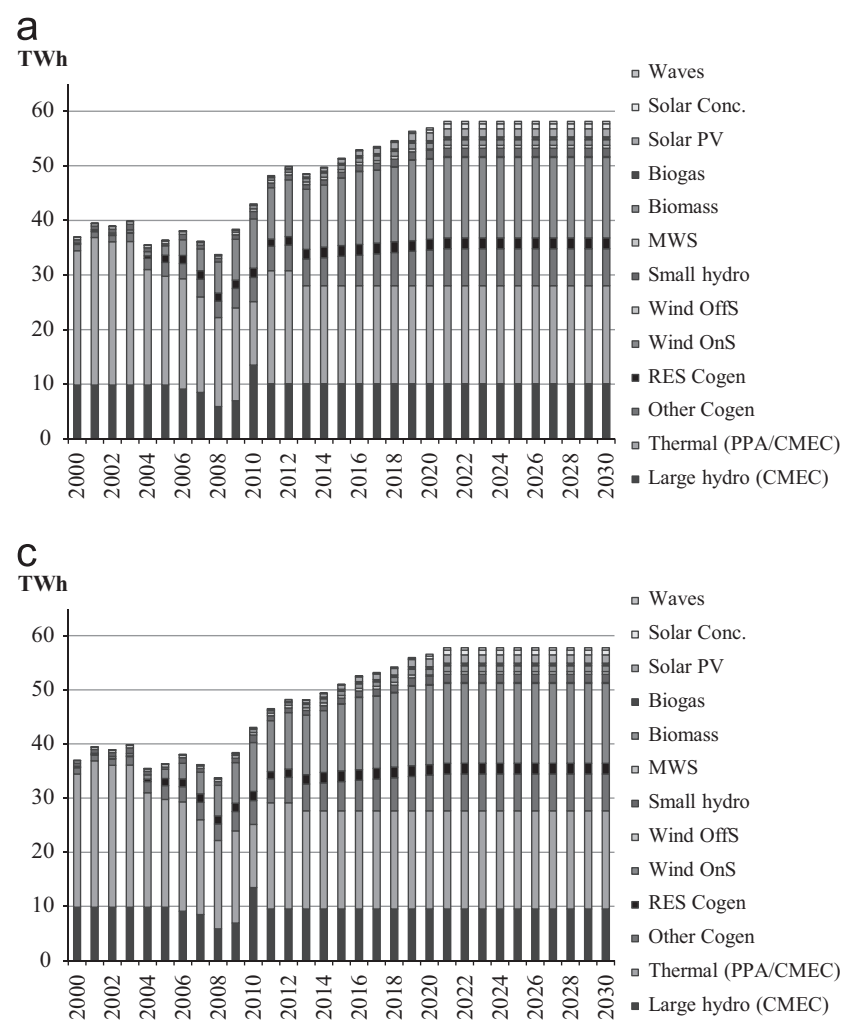

highlighted problems are transitory. In the mean time, given the foreseen development of the generation system, it will be important to address two main issues:

- balancing mechanisms to cope with $50 \%$ and more generation from renewable energy sources;

- capacity incentives.

Moreover, it is necessary to design an efficient wholesale market for the period after 2020 , when a large number of fully depreciated, low variable cost power plants will dominate the generation landscape, in Portugal as well as in the Iberian Peninsula as this may represent barriers to entry of new investments.

Price guarantees represent costs to be paid by electricity consumers during the next decades. Based on the data provided in this paper it was be possible to estimate the evolution of legacy costs to be supported by electricity consumers in the future [49].

\section{Acknowledgments}

This work has been supported by the Portuguese Science and Technology Foundation (FCT) through the MIT-Portugal Program and the FCT scholarship SFRH/BD/42988/2008. The fourth author would also like to acknowledge FCT support under project grant PEst-C/EEI/UI0308/2011.

\section{Appendix A. Abbreviations}

$\begin{array}{ll}\text { APREN } & \text { Associação de Energias Renováveis } \\ \text { CCGT } & \text { combined cycle gas turbines } \\ \text { CHP } & \text { combined heat and power or cogeneration } \\ \text { CMEC } & \text { Custos de Manutenção do Equilíbrio Contractual }\end{array}$

b

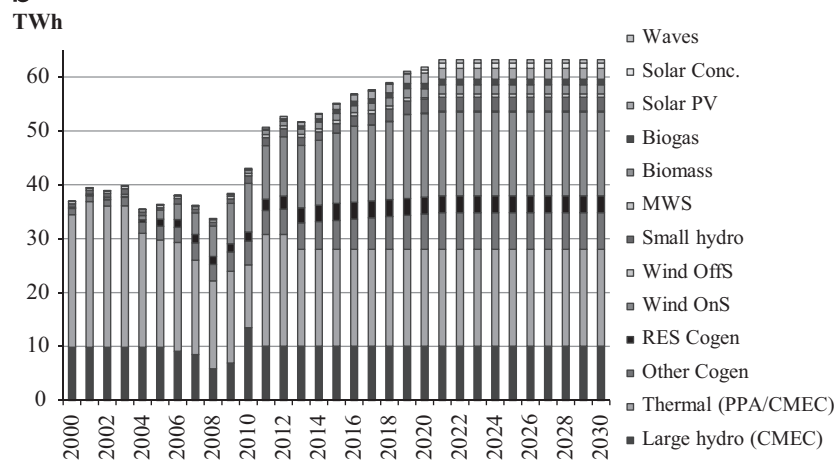

d

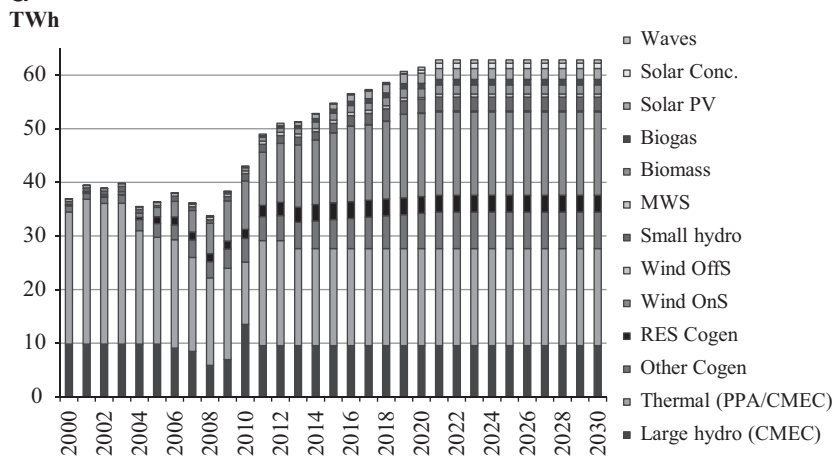

Fig. E1. PPA/CMEC/SR generation in revised market potential analysis: (a) Scenario 1; (b) Scenario 2; (c) Scenario 3; and (d) Scenario 4. 
Table F1

Revised market potential in Generation Scenario 3.

\begin{tabular}{llllll}
\hline Year & $\begin{array}{l}\text { Demand } \\
(\mathbf{1 . 4})\end{array}$ & $\begin{array}{l}\text { Demand } \\
(\mathbf{2 \% )}\end{array}$ & Year & $\begin{array}{l}\text { Demand } \\
(\mathbf{1 . 4 \% )}\end{array}$ & $\begin{array}{l}\text { Demand } \\
(\mathbf{2 \% )}\end{array}$ \\
\hline $\mathbf{2 0 1 1}$ & $12 \%$ & $12 \%$ & $\mathbf{2 0 2 1}$ & $10 \%$ & $17 \%$ \\
$\mathbf{2 0 1 2}$ & $11 \%$ & $11 \%$ & $\mathbf{2 0 2 2}$ & $11 \%$ & $18 \%$ \\
$\mathbf{2 0 1 3}$ & $13 \%$ & $14 \%$ & $\mathbf{2 0 2 3}$ & $12 \%$ & $18 \%$ \\
$\mathbf{2 0 1 4}$ & $12 \%$ & $14 \%$ & $\mathbf{2 0 2 4}$ & $12 \%$ & $19 \%$ \\
$\mathbf{2 0 1 5}$ & $11 \%$ & $14 \%$ & $\mathbf{2 0 2 5}$ & $13 \%$ & $20 \%$ \\
$\mathbf{2 0 1 6}$ & $11 \%$ & $14 \%$ & $\mathbf{2 0 2 6}$ & $14 \%$ & $21 \%$ \\
$\mathbf{2 0 1 7}$ & $11 \%$ & $15 \%$ & $\mathbf{2 0 2 7}$ & $15 \%$ & $22 \%$ \\
$\mathbf{2 0 1 8}$ & $11 \%$ & $16 \%$ & $\mathbf{2 0 2 8}$ & $15 \%$ & $23 \%$ \\
$\mathbf{2 0 1 9}$ & $11 \%$ & $16 \%$ & $\mathbf{2 0 2 9}$ & $16 \%$ & $24 \%$ \\
$\mathbf{2 0 2 0}$ & $11 \%$ & $17 \%$ & $\mathbf{2 0 3 0}$ & $17 \%$ & $24 \%$ \\
\hline
\end{tabular}

Table F2

Revised market potential in Generation Scenario 2.

\begin{tabular}{lllllc}
\hline Year & $\begin{array}{l}\text { Demand } \\
(\mathbf{1 . 4 \%})\end{array}$ & $\begin{array}{l}\text { Demand } \\
(\mathbf{2 \%})\end{array}$ & Year & $\begin{array}{l}\text { Demand } \\
(\mathbf{1 . 4 \% )}\end{array}$ & $\begin{array}{l}\text { Demand } \\
(\mathbf{2 \% )})\end{array}$ \\
\hline $\mathbf{2 0 1 1}$ & $4 \%$ & $4 \%$ & $\mathbf{2 0 2 1}$ & $1 \%$ & $8 \%$ \\
$\mathbf{2 0 1 2}$ & $2 \%$ & $3 \%$ & $\mathbf{2 0 2 2}$ & $2 \%$ & $9 \%$ \\
$\mathbf{2 0 1 3}$ & $6 \%$ & $7 \%$ & $\mathbf{2 0 2 3}$ & $3 \%$ & $10 \%$ \\
$\mathbf{2 0 1 4}$ & $5 \%$ & $7 \%$ & $\mathbf{2 0 2 4}$ & $4 \%$ & $11 \%$ \\
$\mathbf{2 0 1 5}$ & $4 \%$ & $7 \%$ & $\mathbf{2 0 2 5}$ & $5 \%$ & $12 \%$ \\
$\mathbf{2 0 1 6}$ & $3 \%$ & $6 \%$ & $\mathbf{2 0 2 6}$ & $5 \%$ & $13 \%$ \\
$\mathbf{2 0 1 7}$ & $3 \%$ & $8 \%$ & $\mathbf{2 0 2 7}$ & $6 \%$ & $14 \%$ \\
$\mathbf{2 0 1 8}$ & $3 \%$ & $8 \%$ & $\mathbf{2 0 2 8}$ & $7 \%$ & $15 \%$ \\
$\mathbf{2 0 1 9}$ & $2 \%$ & $8 \%$ & $\mathbf{2 0 2 9}$ & $8 \%$ & $16 \%$ \\
$\mathbf{2 0 2 0}$ & $3 \%$ & $9 \%$ & $\mathbf{2 0 3 0}$ & $8 \%$ & $17 \%$ \\
\hline
\end{tabular}

COGEN Port. Ass. Port. para Eficiência Energética e

$\begin{array}{ll}\text { CPV } & \text { Promoção da Cogeração } \\ \text { CSP } & \text { concentrated photovoltaic } \\ \text { CUF } & \text { concentrated solar power } \\ \text { DGC } & \text { Directorate General for Competition } \\ \text { DGEG } & \text { Direcção Geral de Energia } \\ \text { EDP } & \text { Grupo Electricidade de Portugal } \\ \text { ERSE } & \text { Entidade Reguladora dos Serviços Energéticos } \\ \text { IEM } & \text { internal electricity market } \\ \text { INEGI } & \text { Inst. Engenharia Mecânica e Gestão Industrial } \\ \text { MIBEL } & \text { Iberian Electricity Market } \\ \text { MWS/IR } & \text { municipal waste sewage and industrial residues } \\ \text { NREAP } & \text { National Renewable Energy Action Plan } \\ \text { OMEL } & \text { Iberian Electricity Spot Market Operator } \\ \text { OMIP } & \text { Iberian Electricity Derivatives Market Operator } \\ \text { OR } & \text { ordinary regime } \\ \text { PPA } & \text { power purchase agreements } \\ \text { PV } & \text { photovoltaic } \\ \text { PHI } & \text { Productibility Hydroelectric Index } \\ \text { REN } & \text { Rede Eléctrica Nacional } \\ \text { RES } & \text { renewable energy sources } \\ \text { SR } & \text { special regime }\end{array}$

\section{Appendix B. Capacity utilization factors}

See Tables B1-B5.

\section{Appendix C. Guaranteed price generation in market potential scenarios analysis}

See Fig. C1.

\section{Appendix D. Market potential}

See Tables D1 and D2

\section{Appendix E. Guaranteed price generation in revised market potential scenarios analysis}

See Fig. E1.

\section{Appendix F. Revised market potential}

See Tables F1-F2

\section{References}

[1] Decree-Law no 182/1995, July 27th 1995.

[2] Decree-Law no 183/1995, July 27th 1995.

[3] Decree-Law no 184/1995, July 27th 1995.

[4] Decree-Law no 185/1995, July 27th 1995.

[5] Decree-Law no 186/1995, July 27th 1995.

[6] Decree-Law no 187/1995, July 27th 1995.

[7] Decree-Law no 29/2006, February 15th 2006.

[8] Decree-Law no 172/2006, August 23rd 2006.

[9] Decree-Law no 264/2007, July 24th 2007.

[10] Decree-Law no 240/2004, December 27th 2004.

[11] Decree-Law no 392/2007, June 1st 2007.

[12] Ordinance no 765/2010, August 20th 2010

[13] Borenstein Severin, Bushnell James B, Wolak Frank A. Measuring market inefficiencies in California's restructured wholesale electricity market. American Economic Review 2002;92(December (5)):1376-405.

[14] Bushnell James B, Mansur Erin T, Saravia Celeste. Vertical arrangements, market structure, and competition: an analysis of restructured U.S. electricity markets. Working paper 13507. National Bureau of Economic Research; October 2007.

[15] Ferrari Alessandra, Giulietti Monica. Competition in electricity markets: international experience and the case of italyUtilities Policy 2005;13(3): 247-55.

[16] Hrovatin Nevenka, Pittman Russell, Zori Jelena. Organisation and reforms of the electricity sector in Slovenia. Utilities Policy 2009;17(1):134-43 (The political economy of electricity market reform in South East Europe).

[17] Ferreira Paula, Araújo Madalena, O’Kelly MEJ. An overview of the Portuguese electricity market. Energy Policy 2007;35(3):1967-77.

[18] Fernández Domínguez E, Xiberta Bernat J. Restructuring and generation of electrical energy in the Iberian Peninsula. Energy Policy 2007;35(10): 5117-29.

[19] García Álvarez María Teresa, Mariz Pérez Rosa María. Efectos de la liberalización en el pool eléctrico español: eficiencia o comportamiento estratégico? In: XIX annual meeting of the international association of applied economics (ASEPELT) (ASEPELT); 2005.

[20] Agosti Luis, Jorge Padilla A, Requejo Alejandro. El mercado de generación eléctrica en España: estructura, funcionamiento y resultadosEconomía Industrial 2007;364:21-37.

[21] Decree-Law no 189/88, May 27th 1988.

[22] Decree-Law no 199/2007, May 18th 2007.

[23] ERSE. Análise da aplicação do Decreto-Lei no 240/2004; 2005.

[24] REN. Dados Técnicos da REN 2009; 2010.

[25] REN. SRP production and capacity connected 2000-2010; 2011.

[26] REN. Estatística anual 2000-2009; 2010.

[27] ERSE. Ajustamentos referentes a 2009 e 2010 a repercutir nas tarifas de 2011; 2010.

[28] ERSE. Ajustamentos referentes a 2008 e 2009 a repercutir nas tarifas de 2010; 2009.

[29] ERSE. Ajustamentos referentes a 2007 e 2008 a repercutir nas tarifas de 2009; 2008.

[30] ERSE. Ajustamentos referentes a 2006 e 2007 a repercutir nas tarifas de 2008; 2007.

[31] ERSE. Tarifas e preços para a energia eléctrica e outros serviços em 2007; 2006.

[34] ERSE. Proveitos permitidos das empresas reguladas do sector eléctrico em 2009; 2008.

[35] ERSE. Proveitos permitidos das empresas reguladas do sector eléctrico em 2010; 2009.

[36] ERSE. Proveitos permitidos das empresas reguladas do sector eléctrico em 2011; 2010.

[37] ERSE. Informação sobre produção em regime especial (PRE) em Portugal continental-Dez. 2010; 2011.

[38] National Accounts Statistics Portugal. GDP at market prices from the expenditure side (current prices; annual) (Base 2006); 2011. 
[39] OECD/IEA. Energy policies of IEA countries. Portugal 2009 review; 2009.

[40] EDP. Novas barragens - centros produtores EDP-viva a nossa energia $\langle$ www.a-nossa-energia.edp.pt ; 2010.

[41] INAG and DGEG. Programa Nacional de Barragens com Elevado Potencial Hidroeléctrico (PNBGPH) 〈http://pnbeph.inag.pt >; 2007.

[42] Government of Portugal. National renewable action plan, Portugal; October 2010.

[43] APREN. Roteiro Nacional das Energias Renováveis (Anexos); March 2010.

[44] REN. Plano de desenvolvimento e investimento da rede de transporte de electricidade 2012-2017 (2022). (Consulta Pública); 2011.
[45] EPD. EDP produção em números 2010; 2011.

46] DGEG. Renováveis. Estatísticas Rápidas. Janeiro/Fevereiro 2011; 2011.

[47] E-VALUE. Roadmap Portugal 2050; 2011.

[48] ERSE. Tarifas e preços para a energia eléctrica e outros serviços em 2010; 2009

[49] Amorim Filipa, Vasconcelos Jorge, Abreu Isabel C, Silva Patrícia P, Martins Victor. Assessment of generation legacy contracts'costs in the future Portuguese Electricity System. In: 9th international conference on the European energy market (EEM'12); 2012. 